\title{
Bioactive Marine Alkaloids
}

\begin{abstract}
The chapter deals with bioactive marine alkaloids. The chemistry and biological activities of pyridoacridines, pyrroloacridines, indoles, $\beta$-carbolines, pyrroles, isoquinolines, and tyrosine derived alkaloids have been discussed and reviewed.
\end{abstract}

\section{Introduction}

The alkaloids are generally defined as naturally occurring basic nitrogenous compounds. Majority of this class of compounds display biological activity. The reviewers ${ }^{1-4}$ of tharine alkaloids'have, therefore, included amino acids, purines, primidines and their nucleosides, peptides, nitrogenous marine toxins, guanidine etc. under tharine alkaloids.'The chemistry and biological activities of marine toxins, nucleosides and peptides have been dealt separately in Chapters 7, 8 and 10, respectively. The chemistry and biological activities of the bioactive marine alkaloids for convenience have been discussed and reviewed.

\section{Pyridoacridine Alkaloids}

Marine pyridoacridine alkaloids have been the subject of intense study due to their significant biological activities. ${ }^{4-13}$ Over 75 pyridoacridine alkaloids have been isolated and characterized from marine source and it is expected that more of these alkaloids will be isolated in future. Almost all known pyridoacridine alkaloids are reported to have significant cytotoxicity. The compounds of this group also display several specific biological properties, such as inhibition to topoisomerase $\mathrm{II},{ }^{12-14}$ antiHIV activity, ${ }^{15} \mathrm{Ca}^{2+}$ release activity ${ }^{16}$ metal chelating properties ${ }^{17}$ and intercalation of DNA ${ }^{17}$ property. 
Pyridoacridines have a common tetracyclic heteroaromatic parent-pyrido [4,3,2-m,n]acridine (1) system. They are distributed across several phyla of marine invertebrates which are an intriguing fact, and it needs further investigation. One possibility is that in the biosynthesis of these alkaloids probably symbiotic microbes are involved, but it has not yet been tested. Marine pyridoacridine alkaloids have been reviewed extensively. ${ }^{18-23}$

\subsection{Occurrence and Chemical Properties}

Pyridoacridines have been isolated from marine sponges, tunicates, anemone and molluscs which are often ornately decorated with bright colors and patterns. Tropical tunicates (ascidians) in particular are generally richly pigmented in colors which vary from yellow to deep red, orange, blue and purple. It is often found that pyridoacridines isolated from such tunicates are the pigments (zoochromes) responsible for their coloration. Pyridoacridines act as a pH indicator. The indicator properties is correlated with the presence of at least two basic pyridine like nitrogen and is probably associated with electronic perturbations of an extended chromophore with charge-transfer properties. Simple indicator properties are absent in the less basic iminoquinones, such as cytodytin-A (2) and diplamine (3). Alkaline solution of the free base generally appears orange or red, while in acidic solution they are green-blue to purple. Some quaternary ammonium alkaloids, like petrosamine (4), are deep blue or purple salts.

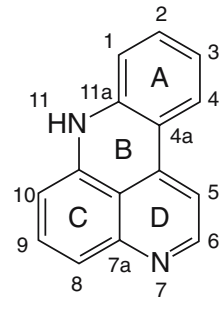

1

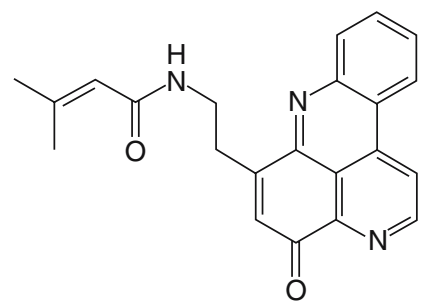

2<smiles>CC(=O)NCCC1=C(S(C)(C)C)C(=O)c2nccc3c2c1nc1ccccc13</smiles>

3

Pyridoacridines are generally obtained as microcrystalline solids with melting points above $300^{\circ} \mathrm{C}$. They have also been isolated as hydrochloride salts. Few pyridoacridines are found to be optically active. The optical activity of these compounds is due to the presence of additional asymmetric side chain. The majority of pyridoacridine alkaloids have planar heterocyclic system.

Because of variability in oxidation states of the heterocyclic nucleus, pyridoacridines exhibit facile redox reactions. For example, the iminoquinone substructure (5) in many alkaloids is easily reduced by $\mathrm{NaBH}_{4}$. Partially saturated nitrogen containing rings in pyridoacridines are easily aromatized by air oxidation (auto oxidation) upon storage or heating in solution. Although 
several pentacyclic pyridoacridines have a 1,10-phenanthroline subunit, they do not react with $\mathrm{Fe}$ (II) salts to form red complexes. This lack of reactivity must be interpreted cautiously while assigning possible structures to new alkaloids as it does not provide evidence for lack of 1,10-phenanthroline substructure.<smiles></smiles>

4<smiles>O=C1C=Cc2nc3ccccc3c3ccnc1c23</smiles>

5

\subsection{Assignment of Structure}

The assignment of structure in general by NMR in highly condensed heterocyclic aromatic compounds is complicated because of the difficulty in defining the correct regioisomer from among many possibilities. However, these problems can be solved by employing new powerful multipulse NMR techniques like HMQC, HMBC, INADEQUATE, INAPT. $J_{\mathrm{CH}}$ Coupling constant analysis has been helpful in the resolution of ambiguous structural assignments. When suitable crystals of the compound are available, single crystal X-ray diffraction analysis has given definitive structures. Because the ring system (1) is highly conserved, some general features in the appearance of the ${ }^{1} \mathrm{H}$ NMR spectra are common to most of these alkaloids and useful in identifying a member of this class of compounds. The disubstituted benzo ring A gives rise to a distinctive linear four proton coupled spin network $\left(\mathrm{H}_{1}-\mathrm{H}_{4}, 7.0-9.0 \mathrm{ppm}, J=8-9 \mathrm{~Hz}\right)$ with $\mathrm{H}_{1}$ resonating at lowest field due to the deshielding acridine nitrogen. A second $\mathrm{AB}$ spin system (8.5, $9.0 \mathrm{ppm}$, $J=5.6 \mathrm{~Hz}$ ) is assignable to $\mathrm{H}_{5}-\mathrm{H}_{6}$, the protons of a trisubstituted pyridine ring. A strong NOE (ca. 20\%) is seen between the two bay region'protons, $\mathrm{H}_{4}-\mathrm{H}_{5}$, thus, linking these two nonscalar-coupled substructures.

\subsection{Structural Subtypes}

Pyridoacridines vary in structure by appendage of different side chains or fusion of rings to ring $\mathrm{C}$, and occasionally to the acridine nitrogen. Halogen substitution in the pyridoacridines are rarely seen, and when present, this is always bromine at $\mathrm{C}_{2}$ in ring $\mathrm{A}$. Oxidation states of the rings vary, and in some cases ring $\mathrm{D}$ is partially saturated. Additional rings are more commonly appended to ring $\mathrm{C}$. 


\section{Tetracyclic Alkaloid}

The yellow tunicate Cystodytes dellechiajei from Okinawa has yielded nine cytotoxic tetracyclic pyridoacridine alkaloids named cystodytins A-I (2, 6-11). ${ }^{16,24}$ The cystodytins A-C are the first tetracyclic pyridoacridine alkaloids isolated from a marine tunicate. Colored tunicate ( $900 \mathrm{~g}$, wet weight) was collected and kept frozen until used. The methanol-toluene (3:1) extract of $C$. dellechiajei was partitioned with toluene and water. It was observed that toluene soluble portion exhibited potent cytotoxicity against L1210 murine leukemia cells. The toluene soluble portion was chromatographed by using $\mathrm{CHCl}_{3} / \mathrm{CH}_{3} \mathrm{OH}(98.5: 1.5)$ as an eluant followed by a Sephadex LH-20 column $\left(\mathrm{CHCl}_{3} / \mathrm{CH}_{3} \mathrm{OH}, 1: 1\right)$ to yielded yellow crystals of cystodytins $\mathrm{A}(2)$ and $\mathrm{B}$ (6) in $0.022 \%$ yield. Separation of (2), and (6) was very difficult as both of the compounds had the same retention times on HPLC, silica gel or ODs under different solvent systems. The aqueous layer also exhibited modest cytotoxicity against L1210 and was purified by the same procedure and afforded cystodytin C (7) in $0.0003 \%$ yield as yellow crystals in addition to $38 \mathrm{mg}$ of mixture of cystodytin A and B. Both of the compounds were separated, and EIMS of free base (2) showed the molecular ion at $\mathrm{m} / \mathrm{z} 357$ $\left(\mathrm{M}^{+}\right)$. Molecular formula for compound (2) was determined to be $\mathrm{C}_{22} \mathrm{H}_{19} \mathrm{~N}_{3} \mathrm{O}_{2}$ by FAB-HRMS $(\mathrm{m} / \mathrm{z} 357.1707)$. The UV spectrum of (2) exhibited absorptions at $225(\varepsilon 35000), 272$ ( $\varepsilon 25000)$, and $380(\varepsilon$ 14300) $\mathrm{nm}$. Absorption at 1640 and $1660 \mathrm{~cm}^{4}$ in IR and the resonances at $\delta 167.8-170.3$ and 183.2 in the ${ }^{13} \mathrm{C}$ NMR indicated the presence of an amide and a conjugated ketone carbonyl group, respectively in compound (2). The RCT-COSY spectrum of (2) revealed cross peaks of H-5 to H-6, H-9 to H2-12 and H2-13, H2-12 to H2-13, H-16 to $\mathrm{H} 3-18$ and $\mathrm{H} 3-19, \mathrm{H} 3-18$ to $\mathrm{H} 3-19$, and among $\mathrm{H}-1-\mathrm{H}-4$, respectively. The final structure of compound (2) was determined with the help of ${ }^{1} \mathrm{H}-{ }^{13} \mathrm{C}$ COSY experiments.

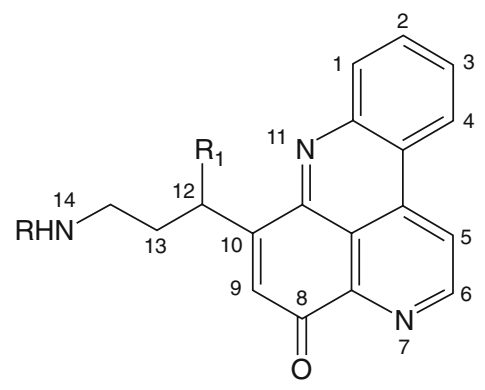
6, $\mathrm{R}=\mathrm{Y}, \mathrm{R}_{1}=\mathrm{H}$
7, $\mathrm{R}=\mathrm{Z}, \mathrm{R}_{1}=\mathrm{H}$
8, $\mathrm{R}=\mathrm{X}, \mathrm{R}_{1}=\mathrm{OH}$
9, $\mathrm{R}=\mathrm{Y}, \mathrm{R}_{1}=\mathrm{OH}$
10, $R=X, R_{1}=O M e$
11, $R=Y, R_{1}=O M e$

12, $\mathrm{R}=\mathrm{X}, \mathrm{R}_{1}=\mathrm{OCO}\left(\mathrm{CH}_{2}\right)_{7} \mathrm{CH}=\mathrm{CH}\left(\mathrm{CH}_{2}\right)_{7} \mathrm{CH}_{3}$ 13, $\mathrm{R}=\mathrm{Y}, \mathrm{R}_{1}=\mathrm{OCO}\left(\mathrm{CH}_{2}\right)_{7} \mathrm{CH}=\mathrm{CH}\left(\mathrm{CH}_{2}\right)_{7} \mathrm{CH}_{3}$<smiles>[Y][Y]C(=O)C=C(C)C</smiles><smiles>[Y][Y]C(=O)/C(C)=C/C</smiles><smiles>[Z][Y]C(=O)CC(C)(C)O</smiles> 
Cystodytins D-I (8-13) are chiral levorotatory compounds, due to the presence of 2-amido-1-hydroxyethyl side chain, $\mathrm{N}$-substituted with one of the above mentioned $\mathrm{C}_{5}$ carboxylic acids. Hydration of Cystodytin-A $(2,6 \%$ aqueous $\mathrm{HCl} 100^{\circ} \mathrm{C}, 3 \mathrm{~h}$ ) gives cystodytin $\mathrm{C}(7)$. When treated with diazomethane, (2) formed a methylether (14) (23\%). This transformation is unusual as it constitutes a reductive methylation. The iminoquinone system in (2) is readily reduced in the ionization stage of a mass spectrometer, $(\mathrm{M}+2$ ion in EIMS, $\mathrm{MH}+2$ for FABMS $)$, a typical for quinones. The vivid purple-colored ascidian Lissoclinum vareau ${ }^{25}$ from Fiji has furnished two bright crimson pigments varamine-A (16) and varamine-B (17) which occurs with antitumor alkaloid, varacin (15). ${ }^{26}$ Varamine-A (16) and varamine-B (17) have a parent tetracyclic aromatic ring system at the same oxidation level as the systodytin-A methylation product (14). However, the varamines also contain a methyl thioether substituted at $\mathrm{C}_{9}$.

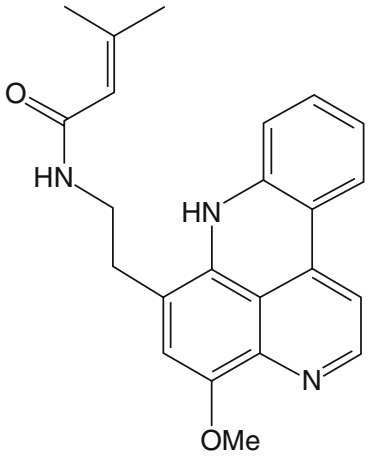

14

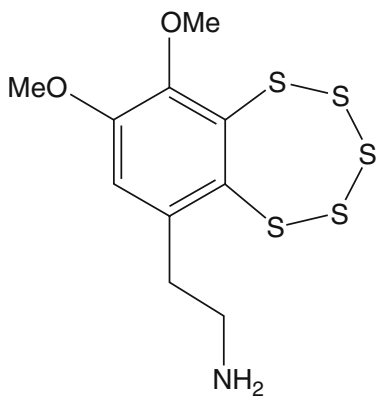

15

The bright red tunicate Lissoclinum vareau (Monniot and Monniot, 1987), was collected from Yasawa Island chain, in the Fiji Island. Crude methanol extract of the tunicate exhibited potent antifungal and cytotoxicity against the L1210 murine leukemia cell line. The chloroform soluble fraction of the extract yielded two bright red pigments, varamine A (16) and varamine B (17). The spectral data of (16) and (17) revealed that the two compounds $(\mathbf{1 6}, \mathbf{1 7})$ were related as homologues, and structure elucidation was carried out primarily on the trifluoroacetate salt of $\mathbf{1 6}$. Molecular formula of varamine A (16) was determined to be $\mathrm{C}_{22} \mathrm{H}_{23} \mathrm{~N}_{3} \mathrm{O}_{2} \mathrm{~S}$ by FABMS data $(\mathrm{m} / z 394.1589$ $\mathrm{M}^{+}$). The ultraviolet spectrum of the free base of (16) revealed strong bands from 232 to $494 \mathrm{~nm}$. In particular, the striking color change from yellow to intense red upon acidification of the freebase of (16) was correlated with a reversible bathochromic shift $464 \mathrm{~nm}(\varepsilon 5170)$ to $527 \mathrm{~nm}(\varepsilon 5670 \mathrm{~nm})$. In the ${ }^{1} \mathrm{H}$ NMR of TFA salt of (16) six proton signals found between $\delta 7.20$ and $8.30 \mathrm{ppm}$ were assigned to deshielded protons of the heteroaromatic ring. The resonance at $\delta 7.52(d, J=6.5 \mathrm{~Hz})$ and $8.21(\mathrm{~d}, J=6.5 \mathrm{~Hz})$ were assigned to $\mathrm{H}-5$ and $\mathrm{H}-6$, respectively, in a trisubstituted pyridine ring. 
A strong nuclear overhauser effect from $\mathrm{H}-5$ to $\mathrm{H}-4$ indicates the close proximity of the respective ring residues. Stretches around 1650 and at 3200, 3280 , and $3450 \mathrm{~cm}^{+}$confirmed the presence of amide, and $\mathrm{NH}$ functionalities. A thiomethyl group $\left(\mathrm{SCH}_{3}\right)$ appeared as singlet of three proton at $\delta 2.66$. Additional evidence comes from ${ }^{1} J_{\mathrm{CH}}$ values for the methyl groups; these were most easily obtained by measuring the separation of the inner peaks of the methyl ${ }^{13} \mathrm{C}$ satellites in the proton spectrum of $(\mathbf{1 6})$ or $(\mathbf{1 7})$. The moderately large one bond coupling constant $\left({ }^{1} J_{\mathrm{CH}}=141 \mathrm{~Hz}\right)$ for the methyl carbon at $18.7 \mathrm{ppm}$ is similar to that measured for the electronegative methoxy group. Finally structure (16), and (17) were confirmed by 2D NMR spectroscopy. Ring C of varamine-A (16) isoelectronic with hydroquinone, was readily oxidized by aqueous ceric ammonium nitrate to the iminoquinone (18) in quantitative yield. ${ }^{25}$ The corresponding oxidation product (3) of varamine-B (17) was found identical with diplamine from the Fijian tunicate, Diplosoma $\mathrm{sp}^{27}$ Another homologue in this series, isobutyramide (19), ${ }^{18,27}$ has been characterized from an unidentified Australian tunicate.

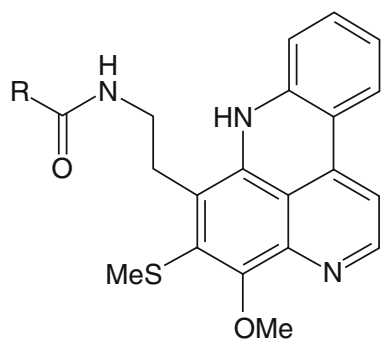

16, $\mathrm{R}=\mathrm{CH}_{2} \mathrm{CH}_{3}$ 17, $\mathrm{R}=\mathrm{CH}_{3}$

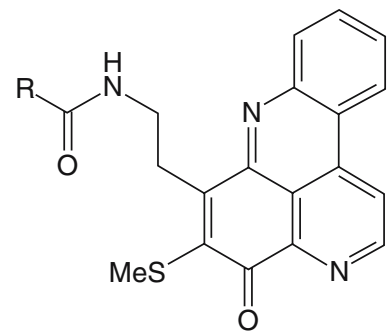

18, $\mathrm{R}=\mathrm{CH}_{2} \mathrm{CH}_{3}$ 19, $\mathrm{R}=\mathrm{CH}\left(\mathrm{CH}_{3}\right)_{2}$

\section{Pentacyclic Alkaloids}

The pentacyclic pyridoacridine alkaloids could be classified into two groups: (a) those having one additional angular-fused ring at $\mathrm{C} 9,10$ of the acridine system at $\mathrm{C} 8, \mathrm{C} 9$ of ring $\mathrm{C}$ and (b) those having linear-ring fusion at $\mathrm{C} 8, \mathrm{C} 9$ of ring C. Typical ring appendages include pyridine, tetrahydropyridine, pyridone, thiazine, or even a thiazole heterocycle. In some cases, a substituted 2-ethylamino side chain is also attached to the acridine $\mathrm{C}$ ring. The bright yellow zoochrome calliactine isolated from the mediterranean anemone, Calliactis parasitica, has a long history and is probably the first marine pyridoacridine alkaloid isolated from marine organisms. Calliactine attracted the attention of Lederer et $\mathrm{al}^{28}$ in 1940 and later by Barbier ${ }^{29}$ however, the structure determination work was hampered by low solubility of the compound and the difficulties in purification. In 1987, Cimino et $\mathrm{al}^{30}$ reported their studies on the degradation and NMR spectroscopy of calliactine and its derivatives. Calliactine is readily aromatized (presumably autoxidation elimination with concomitant hydrolytic loss of ammonia) by boiling with dilute $\mathrm{HCl}$ to give \&hlorocalliactine"or with water to give fheocalliactine" 
which in turn yielded neocallicatine acetate when treated with acetic anhydride in pyridine. The molecular formula $\mathrm{C}_{18} \mathrm{H}_{21} \mathrm{~N}_{4} \mathrm{O}$ was established for calliactine, and several possible structures (20a-20d) were advanced. Four possible structures (21a-21d) for neocalliactine acetate were also proposed. However, definitive assignments have not yet been reported on either of these compounds. The amphimedine (22) is the first pyridoacridine alkaloid to be fully characterized. ${ }^{31} \mathrm{Schmitz}$ et al ${ }^{31}$ isolated amphimedine (22), a sparingly soluble yellow solid (m.p. $360^{\circ} \mathrm{C}$ ) sponge Amphimedon sp. was collected from Guam Island. Ambient temperature extraction with $\mathrm{CH}_{2} \mathrm{Cl}_{2}, \mathrm{CHCl}_{3}-\mathrm{MeOH}, \mathrm{MeOH}$ followed by hot Soxhlet extraction with $\mathrm{CHCl}_{3}$ and finally purification by coloumn chromatography yielded pure compound. Molecular formula of (22) was established as $\mathrm{C}_{19} \mathrm{H}_{11} \mathrm{~N}_{3} \mathrm{O}_{2}$ by high-resolution mass spectral analysis $\left(\mathrm{m} / \mathrm{z} 313.08547, \mathbf{M}^{+}\right)$. In the mass spectrum few fragments were observed which indicated that the compound is highly stable. The electronic absorption<smiles></smiles>

20a<smiles>N=C1c2nccc3c2c(nc2ccc(O)cc23)C2NCC[C@@H](O)C12</smiles>

20d<smiles>N=C1CCNC2=C1c1c2nccc2c3cc(O)ccc3nc1C(O)CCN2</smiles>

$20 b$<smiles>CC(=O)Oc1ccc2nc3c4c(nccc4c2c1)-c1cccnc1C3=O</smiles>

$21 a$<smiles></smiles>

20c<smiles>CC(=O)Oc1ccc2nc3c4c(nccc4c2c1)-c1ncccc1C3=O</smiles><smiles></smiles>

21c<smiles>CC(=O)Oc1ccc2c(c1)-c1ccnc3c(=O)c4nc(OC(C)=O)ccc4nc-2c13</smiles>

21d<smiles>[R]c1c2c(cn(C)c1=O)C(=O)c1nccc3c1c-2nc1ccccc13</smiles>

22, $\mathrm{R}=\mathrm{H}$

23, $\mathrm{R}=\mathrm{Br}$ 
spectra of 22 showed absorption at $\lambda_{\max } 210$ (ع 19690), 233 (ع 39393), 281 ( $\varepsilon$ 9099), 341( $\varepsilon$ 6060). Significant changes were observed in the absorption with $\mathrm{NaBH}_{4}\left[\lambda_{\max } \mathrm{nm} 235\right.$ ( $\varepsilon$ 12879), 280 ( $\varepsilon$ 9090)], suggesting the presence of conjugated carbonyl functionality. Two strong absorptions 1690 and $1640 \mathrm{~cm}^{+}$in the IR spectrum confirmed the presence of two carbonyl groups. Further since the absorption was observed at lower frequency so these peaks were attributed to $\alpha, \beta$-unsaturated ketone and amide functionalities, respectively. The ${ }^{13} \mathrm{C}$ NMR data reconfirmed the presence of an amide carbonyl $(\mathrm{C}-11, \delta 165.9)$ and a cross-conjugated ketone $(\mathrm{C}-8, \delta$ 175.0). The 2D NMR ${ }^{13} \mathrm{C}-{ }^{13} \mathrm{C}$ INADEQUATE NMR techniques were used for the structural elucidation of amphimedine (22). ${ }^{3234}$

Amphimedine (22) is selectively brominated $\left(\mathrm{Br}_{2}\right.$, acetic acid) to give the mono bromo derivative (23). Neoamphimedine (24), ${ }^{23}$ along with amphimedine (22) and debromopetrosamine (25a), have been isolated from the Micronesian sponge Xestospongia carbonaria. ${ }^{9}$ Neoamphimedine (24) is a regioisomer of amphimedine (22). Kobayashi et $\mathrm{al}^{35}$ have isolated ascididemin (26) ${ }^{6,17,36}$ from a species of Didemnum collected in Okinawa. The structural proof relied on extensive use of long-range ${ }^{1} \mathrm{H}^{13}{ }^{13} \mathrm{C}$ correlation (COLOC) data and comparison, with the properties of amphimedine (22). It is noteworthy that ascididemin (26), like related pyridoacridine alkaloids which have a 1,10-phenanthroline ring system, does not form a bright red complex with $\mathrm{Fe}^{2+}$ that is characteristically observed with 1,10-phenanthroline itself.

Schmitz et $\mathrm{al}^{37}$ have isolated 2-bromoleptoclinidone from Leptoclinides sp. collected in Truk Lagoon. 2-Bromo-leptoclinidone was assigned structure (28) based on interpretation of long range $2 \mathrm{D}^{1} \mathrm{H}^{13} \mathrm{C}$ NMR correlation data and the absence of a color reaction with $\mathrm{Fe}^{2+}$. However, this structure was later revised ${ }^{38}$ and correct structure (27) was shown to have a alternate pyrido ring orientation. ${ }^{38}$ This was confirmed by selective long range $1 \mathrm{D}{ }^{1} \mathrm{H}-$ ${ }^{13} \mathrm{C}$ INAPT experiments ${ }^{39}$ and debromination of bromoleptoclinidone to ascididemin (26).

Pyridoacridine alkaloids had not only been obtained from marine invertebrates of tropical waters, the pentacyclic phenolic alkaloid is also obtained from a South Australian temperate water tunicate Amphicarpa meridiana ${ }^{14}$ and more recently from a Caribbean sponge Corticum sp. ${ }^{40}$ The structure of meridine $(\mathbf{2 9})^{40}$ is determined by single-crystal X-ray diffraction analysis. ${ }^{14}$ An isomer of meridine was also isolated from $A$. meridiana and assigned structure as (30). The regiochemistry of (30) was assigned on the basis of NOE studies. Rapid tautomerism of pyridoacridine alkaloids has been observed. On standing, in $\mathrm{CDCl}_{3}$ compound (30) undergo isomerization to (29) at room temperature. The Caribbean sponge Petrosia sp. when viewed under water looked jet black due to its deep dark pigmentation. Samples were immersed in methanol imparted a deep green-blue color to the solvent. This extract when diluted with water, the color changed to purple. The brominated pigment petrosamine (31a and $\mathbf{3 1 b}$ ) along with tryptamine 
<smiles>Cn1ccc2c(c1=O)C(=O)c1nccc3c1c-2nc1ccccc13</smiles>

24<smiles></smiles>

$25 a$

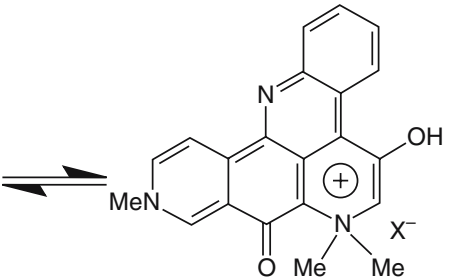

25b<smiles>[R]c1ccc2c(c1)nc1c3c(nccc32)-c2ncccc2C1=O</smiles>

26, $\mathrm{R}=\mathrm{H}$

27, $\mathrm{R}=\mathrm{Br}$<smiles>O=C1c2nccc(O)c2-c2nc3ccccc3c3ccnc1c23</smiles>

29<smiles>O=C1c2cccnc2-c2ccnc3c2c1nc1cc(Br)ccc13</smiles>

28<smiles>O=C1C=CN=c2c1c1[nH]c3ccccc3c3ccnc(c3-1)c2=O</smiles>

30

have been (29) isolated from this extract. ${ }^{41}$ Faulkner et $\mathrm{al}^{41}$ isolated petrosamine (31), from marine sponge Petrosia sp. while attempting to purify an antimicrobial constituent amphimedine (22). Petrosamine is remarkable compound since color of the solution containing (31) changes by the addition of dilute organic or aqueous solutions. It was observed that blue colored methanol extracts of Petrosia sp. exhibited antimicrobial activity against Staphylococcus aureus and Bacillus subtilis. The marine sponge Petrosia sp. was collected from Carrie Bow Cay, Belize and methanol soluble material portion was partitioned to ethyl acetate, n-butanol, and aqueous extracts. A blue band and pale yellow band from n-butanol soluble material was separated on Sephadex LH-20 (MeOH) column. The blue compound was repurified on Sephadex LH-20 column and yielded petrosamine ( $0.1 \%$ dry weight) as dark green crystals, m.p. $>330^{\circ} \mathrm{C}$. Molecular formula of petrosamine was established as $\mathrm{C}_{21} \mathrm{H}_{17} \mathrm{BrN}_{3} \mathrm{O}_{2}$ by high resolution mass spectrum. Both the ${ }^{1} \mathrm{H}$ and ${ }^{13} \mathrm{C}$ NMR spectra indicated the presence of three N-methyl signals, two of which were equivalent. The remaining signals were all in the aromatic region of the 
spectra, except for a ${ }^{13} \mathrm{C}$ NMR signal at $\delta 187.4$ (s) that could be assigned to a single quinone-type carbonyl group. X-ray crystallography in the solid state of petrosamine revealed that the pigment exists as the chloride salt of a quaternized pyridone-acridine ring system (31a). Correlation of the solventdependent changes in the UV and NMR spectra suggested that the remarkable color change observed by varying solvent polarity, was associated with shifts in the position of a keto enol equilibrium, favoring the enol form (31b).<smiles></smiles>

$31 \mathrm{a}$<smiles>Cn1ccc2c3nc4cc(Br)ccc4c4c3c(c(=O)c-2c1)[N+](C)(C)C=C4O</smiles>

31b

The deep-water sponge Dercitus sp. has yielded the dark violet pigment named dercitin (32) together with dimethylindolinium chloride. ${ }^{42}$ The structure of (32) was assigned on the basis of spectroscopic data including 2D INADEQUATE. This structure was subsequently revised to $(\mathbf{3 3})^{17}$ by interpretation of the magnitudes of long-range carbon-proton coupling constants.

The earlier assignment error arose from inherent difficulties in the interpretation of $2 \mathrm{D}{ }^{1} \mathrm{H}_{-}{ }^{13} \mathrm{C}$ NMR spectra in highly condensed heteroaromatic compounds. In the revised structure, the nitrogen and sulphur of the thiazole ring are in correct position relative to other acridine substituents. The thiazole ring proton exhibits different $J_{\mathrm{CH}}$ to each of the two ring junction quaternary carbons, thus providing unambiguous assignment of the respective ${ }^{13} \mathrm{C}$ signals. ${ }^{43}$ The ease with which a partially reduced pyridoacridine system can be aromatized was demonstrated when the dihydropyridoacridine (34), obtained<smiles>CN(C)CCC1=Cc2nccc3c2c(nc2ccccc23)-c2scnc21</smiles>

32<smiles></smiles>

33<smiles>CN(C)CCc1c2c3c(c4ncsc14)Nc1ccccc1C31CC=CN2C1</smiles>

34 
by reduction of dercitin $(\mathbf{3 3})^{44,45}$ with sodium borohydride rapidly autoxidized back to dercitin during workup.

Gunawardana et $\mathrm{al}^{44}$ have reported the isolation of four minor congeners from Dercitus sp. Of these, nordercitin (35) and dercitamine (36) are related to dercitin (33). Reductive methylation of dercitamine $\left(\mathrm{HCO}_{2} \mathrm{H}, \mathrm{HCHO}\right)$ gave nordercitin (35). Dercitamicle (37) contains a propionamide side chain and cyclodercitin (38) is a hexacyclic quaternary salt.

The purple colored colonial tunicate Trididemnum sp. ${ }^{46-48}$ has furnished two related bases, shermilamine-A (39) ${ }^{47}$ and shermilamine-B (40). ${ }^{47}$ Kuanoniamines A-D (41-44), along with shermilamine-B (40), are found in the lamellarid mollusc Chelynotus semperi and its prey, an unidentified tunicate, both collected in Pohnepei. ${ }^{43}$ Kuanoniamines-B (42) and D (44) are homologues of kuanoniamine $\mathrm{C}$ having isovaleramide and acetamide side chains, respectively. Kuanoniamine A (41) differs from the other three alkaloids in lacking the 2-amidoethyl side chain and contains an iminoquinone structure analogous to those found in 2-bromoleptoclinidone and ascididemin.<smiles>[R]CCc1c2c3c(ccnc3c3ncsc13)Nc1ccccc1-2</smiles>

35, $\mathrm{R}=\mathrm{NMe}_{2}$

36, $\mathrm{R}=\mathrm{NHMe}$

37, $\mathrm{R}=\mathrm{NHCOCH}_{2} \mathrm{Me}_{2}$<smiles>O=C1c2scnc2-c2nccc3c2c1nc1ccccc13</smiles>

41<smiles></smiles>

38<smiles>[R]CCC1c2scnc2-c2nccc3c2c1nc1ccccc13</smiles>

42, $\mathrm{R}=\mathrm{NHCOCHMe}_{2}$

43, $\mathrm{R}=\mathrm{NHCOCH}_{2} \mathrm{CH}_{3}$

44, $\mathrm{R}=\mathrm{NHCOCH}_{3}$<smiles>[R]C1=CC=CC2Nc3c(CCNC(C)=O)c4c(c5c3C(=C12)CC=N5)NC(=O)CS4</smiles>

39, $\mathrm{R}=\mathrm{Br}$ 40, $\mathrm{R}=\mathrm{H}$<smiles></smiles>

45

\section{Hexacyclic and Heptacyclic Alkaloids}

Two hexacyclic alkaloids have been reported from the deep-water sponges Dercitus sp. and Stelleta sp. Cyclodercitin (38) is found along with dercitin (33) and other related compounds in Stelleta sp. ${ }^{43}$ The sixth ring in cyclodercitin is formally derived by cyclization of the 2-aminoethyl side chain to the acridine nitrogen, while the pyridine ring is substituted with an $\mathrm{N}$-methyl group. When dissolved in TFA- $d_{4}$ cyclodercitin spontaneously autoxidizes 
to the hexacyclic pyrrolo compound (45). Recently, the hexacylic pyrrolo compound (46) is obtained as a minor compound from Stelleta sp. and its structure has been determined by X-ray analysis.

The red sea tunicate Eudistoma sp. has yielded six alkaloids, including the known pyricloacridine alkaloid shermilamine B $(\mathbf{4 0}) .{ }^{49}$ In addition to these segoline-A (47) and isoegoline-A (48) are regioisomeric hexacyclic pyridoacridine alkaloids.

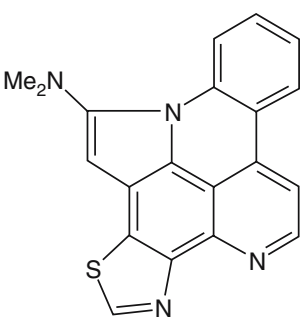

46

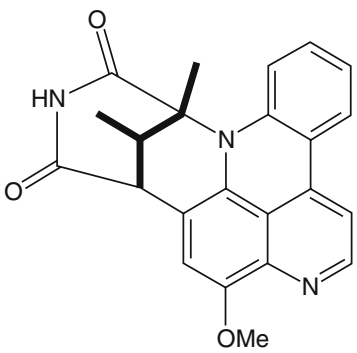

47<smiles>COc1cc2c3c4c(ccnc14)-c1ccccc1N3[C@@H](C)[C@]1(C)C(=O)NC(=O)[C@H]21</smiles>

48

Segoline-A (47) and isosegoline-A (48) are the first optically active pyridoacridines isolated from the marine source. ${ }^{50,51}$ Segoline A (47) was isolated from Eudistoma sp. in $0.4 \%$ (dry weight) yield. Molecular formula of segoline A (47) was established as $\mathrm{C}_{23} \mathrm{H}_{19} \mathrm{~N}_{3} \mathrm{O}_{3}$. Intensive 1D and $2 \mathrm{D}$ NMR experiments such as COSY, NOE, short- and long-range $\mathrm{CH}$ correlations, COLOC, and HETCOSY studies were conducted on (47). The proton NMR data revealed a trisubstituted benzo-3,6-diazaphenanthroline ring system for segoline A. The pyridine ring of the diazaphenanthroline ring was characterized by the $\mathrm{H}-2$ and $\mathrm{H}-3$ signals. The pyridine moiety was hydrogenated easly to the 1,2,3,3a-tetrahydro derivative indicated that it was part of a quinoline ring. The heterocyclic ring system was confirmed by the NOEs between $\mathrm{H}-2$ and $\mathrm{H}-3, \mathrm{H}-3$ and $\mathrm{H}-4, \mathrm{H}-5$ and $\mathrm{H}-6$, and $\mathrm{H}-6$ and H-7. Unequivocal structure of (47) was determined by single X-ray analysis. The structure of isosegoline A (48) is determined by NMR spectroscopic techniques. Segoline B (49) is a diastereoisomer of segoline A (47). In segoline B (49), the bridge across the cyclic imide ring is inverted. This is supported by the strongly bisignated CD curves for (48) and (49), which are almost exactly opposite in sign. The structure of eilatin (50) and unusual pyridoacridine pseudo-dimer," has been solved by X-ray diffraction. Eilatin $(\mathbf{5 0})^{51}$ is the only known heptacyclic pyridoacridine alkaloid.

\section{Octacyclic Alkaloids}

Chiral pyridoacridine alkaloids are rare. Eudistone A (51) and eudistone B (52), the two optically active octacyclic alkaloids obtained from the Seychelles tunicate Eudiste sp. ${ }^{52}$ differ from other members of the class by having additional dihydroisoquinolone bicyclic ring system fused to a quaternary 
<smiles>COc1cc2c3c4c(ccnc14)-c1ccccc1N3C1(C)C(=O)NC(=O)C2C1C</smiles>

49<smiles>c1ccc2c(c1)nc1c3ccccc3nc3c4ccnc5c(c6c2ccnc56)-c4c31</smiles>

50

carbon of the acridine system. The relative stereochemistry of the carbon skeleton was determined by comparison of NMR coupling constants with values predicted from molecular modeling. The two compounds were correlated by autoxidation. Eudistone (51) aromatized to (52) when air is bubbled in a solution of (51) in DMSO. ${ }^{52}$ The circular dichroism spectrum of eudistoneB (52) exhibited a strong bisignate cotton effect. However, the absolute configuration of the two compounds remains unknown.

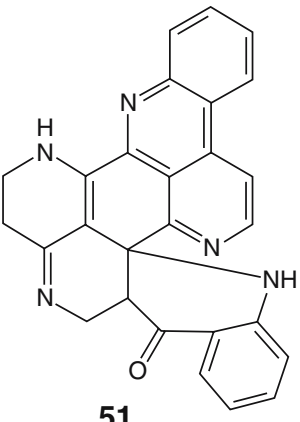

51<smiles></smiles>

52

\section{Pyrroloacridine and Related Alkaloids}

The alkaloids of this group are mostly cytotoxic. Pyrroloacridines have similar ring construction to the pyridoacridine alkaloids. However, they contain a fused pyrrole ring rather than the familiar trisubstituted pyridine ring. The first example of this class are plakinidine ${ }^{5355} \mathrm{~A}(\mathbf{5 3})$ and $\mathrm{B}(\mathbf{5 4})$ which have been isolated from the sponge Plakortis sp. ${ }^{53}$ Ireland et $\mathrm{al}^{56}$ reported the isolation of plakinidine-A (53), B (54) and C (55) from Plakortis sp. collected in Fiji.

Bioassay-guided isolation of red sponge Plakortis has afforded two novel alkaloids named plakinidine-A (53) and B (54). Both of the compounds showed in vitro activity against the parasite Nippostrongylus brasiliensis (at $50 \mathrm{pg} / \mathrm{mL}$ ). A pyrrolo[2,3,4-kl]acridine fused-ring skeleton in (53) and (54), represents a new structural variation within polycyclic aromatic alkaloids 
<smiles>[R]N(C)c1c2c(c3nc4ccccc4c4c3c1N=C4)NCCC2=O</smiles>

53, $\mathrm{R}=\mathrm{H}$

54, $\mathrm{R}=\mathrm{Me}$<smiles>CNc1c2c3c(c4ccccc4nc3c3[nH]ccc(=O)c13)C=N2</smiles>

55

from marine organisms. The organism was collected by scuba at $10 \mathrm{~m}$ off Hideaway island, Port Vila, Vanuatu. Red viscous oil (3.87 g) was obtained from aqueous methanol extracts of the preserved organism $(0.2 \mathrm{~kg}$, wet $)$. The crude oil after partitioned between aqueous $\mathrm{MeOH}$ and the solvent series of hexanes, $\mathrm{CCl}_{4}, \mathrm{CH}_{2} \mathrm{Cl}_{2}$ were separated by column chromatography (reversed phase and Sephadex LH-20/methanol). Plakinidine A (53) was isolated as deep purple solid from methanol (52 mg, 0.026\% wet weight, mp. 248$\left.250^{\circ} \mathrm{C}\right)$ along with $24 \mathrm{mg}(0.012 \%)$ of a purple oil identified as plakinidine $\mathrm{B}$ (54). The molecular formula of (53) was determined as $\mathrm{C}_{18} \mathrm{H}_{14} \mathrm{~N}_{4} \mathrm{O}$, from EI-HRMS $\left(m / z\right.$ 302.1169, $\left.\mathrm{M}^{+}\right)$and an APT ${ }^{13} \mathrm{C}$ NMR spectrum. Four separate proton spin systems were confirmed by COSY experiments in DMSO- $d_{6}$ and $\mathrm{CDC1}_{3}$-TFA- $d_{4}(1: 1)$. Protons on $\mathrm{N}-8$ to $\mathrm{C}-10$ were assigned to a $\mathrm{CH}_{2} \mathrm{CH}_{2} \mathrm{~N}(\mathrm{H})$ group, and protons on C-3 to C-6 were confirmed to be a part of orthodisubstituted benzene ring. Other protons $\mathrm{H}-2$, was a low-field singlet ( $\delta$ 8.84) with a large ${ }^{1} J_{\mathrm{CH}}$ coupling constant $\left(200.4 \mathrm{~Hz}\right.$ in $\mathrm{CDCl}_{3}$-TFA- $d_{4}$ ), indicating a nitrogen was adjacent to $\mathrm{C}-2 .{ }^{57}$ Based on the ${ }^{13} \mathrm{C}$ chemical shifts remaining fragment consisting $\mathrm{C}_{9} \mathrm{~N}$ atoms were assumed to have five double bonds. Long-range ${ }^{1} \mathrm{H}-{ }^{13} \mathrm{C}$ COSY experiments were done to confirm the structure of the compounds. Three bond correlations to $\mathrm{H}-4$ and $\mathrm{H}-5$ revealed the location of quaternary carbons in the molecule. The existence of a sixmembered ring $\beta$-enamino ketone was confirmed by the IR $\left(1624 \mathrm{~cm}^{4}\right)$ and COSY NMR correlations from $\mathrm{H}_{2}-9$ to $\mathrm{C}-7 \mathrm{~b}$ and from $\mathrm{H}_{2}-10$ to $\mathrm{C}-11$ and $\mathrm{C}-$ 1la. Finally, two dimensional ${ }^{13} \mathrm{C}-{ }^{13} \mathrm{C}$ INADEQUATE was used to verify most of the structural elements of plakinidine A. ${ }^{57}$ Bioassay guided purification of the methanol-toluene extract of the tropical green sponge Prianos melanos from Okinawa gave a cytotoxic pigment, prianosin A (56), prianosin B (57), prianosin C (58) and prianosin D (59). 58,59

Several independent reports described the identification of discorhabdins, compounds similar to prianosins. ${ }^{6064}$ The first report described the isolation and structure elucidation of discorhabdin-C (60) an achiral spiro-alkaloid. Discorhabdin-A identical to prianosin-A, (56) was isolated together with discorhabdin-B (61) from three species of Latrunculia sponge collected the 
<smiles></smiles>

56<smiles></smiles>

57

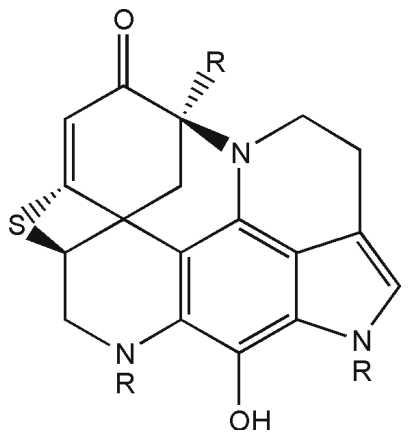

58, $\mathrm{R}=\mathrm{OH}$

$59, \mathrm{R}=\mathrm{H}$

temperate waters around New Zealand. The quaternary iminium salt discorhabdin D (62) is isolated from both Latrunculia brevis, from New Zealand and Prianos sp. from Okinawa. ${ }^{65}$ Each discorhabdin or prianosin contains an unsaturated cyclohexenone and spiro-fused to a tetracyclic ring system. Each ring system, with exception of discorhabdin $\mathrm{C}(\mathbf{6 0})$ is also bridged with tetrahydrothiophene ring. A deep-water collection of Batzella sp. from Bahamas has furnished three pyrroloquinolines, batzellines A-C (63-65). ${ }^{66}$ Each alkaloid has tetrahydroquinoline nucleus further, bridged across both rings by a trisubstituted pyrrole ring. An unusual chlorine atom is present in all the alkaloids.<smiles>O=C1C(Br)=CC2(C=C1Br)CCNC1=C2C2=NCCc3c[nH]c1c32</smiles>

60<smiles></smiles>

61

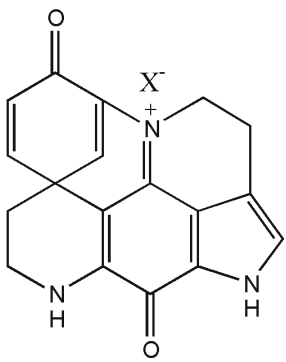

62 
The sponge Bratzella sp. has also furnished four additional pyrroloacridine alkaloids named isobatzellines A-D (66-69). ${ }^{67}$

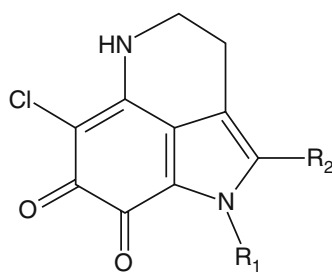

63, $R_{1}=M e, R_{2}=S M e$

64, $\mathrm{R}_{1}=\mathrm{H}, \quad \mathrm{R}_{2}=\mathrm{SMe}$

$65, R_{1}=M e, R_{2}=H$<smiles>[R]c1c2c3c(n1C)C(=O)C(N)=C([3H])C3=NCC2</smiles>

66, $\mathrm{R}_{1}=\mathrm{Cl}, \mathrm{R}_{2}=\mathrm{SMe}$

67, $\mathrm{R}_{1}=\mathrm{H}, \mathrm{R}_{2}=\mathrm{SMe}$

68, $\mathrm{R}_{1}=\mathrm{H}, \mathrm{R}_{2}=\mathrm{Cl}$

Isobatzellines are not strictly isomeric with batzellines, but differ in replacement of one of the quinone carbonyl group with an amino group. Autoxidation of isobatzellin A (66) to D (69) is facile and could be observed within a few hours during thin layer chromatography or treatment with DDQ.

Isobatzelline $\mathrm{A}(\mathbf{6 6})$ can be converted into bratzelline $\mathrm{A}(\mathbf{6 3})$ by diazotization substitution in aqueous nitrous acid. The Fijian tunicate Clavelina sp. ${ }^{68,69}$ has yielded wakayin (70) a unique alkaloid. Ireland et al ${ }^{68,69}$ isolated a new pyrroloiminoquinone based alkaloid, wakayin (70) from the ascidian Clavelina sponge. Wakayin (70) exhibited potent in vitro cytotoxicity against the human colon tumor cell line (HCT116 $\left.\mathrm{IC}_{50} 0.5 \mu \mathrm{g} / \mathrm{mL}\right)$. Wakayin was found to inhibit topoisomerase II enzyme $(250 \mu \mathrm{M})$ and based on related biological data it was concluded that wakayin exhibit its biological activity by damaging the DNA. This compound also exhibited antimicrobial activity against Bacillus subtilis $(\mathrm{MIC}=0.3 \mu \mathrm{g} / \mathrm{mL})$. The crude methanol-chloroform extract was partitioned by reversed phase flash chromatography using methanol-aqueous trifluoroacetic acid solvent systems. Purification of combined biologically active fractions by repeated elution through Sephadex LH-20 yielded $15 \mathrm{mg}$ $(0.005 \%$ wet weight) of wakayin (70) as a triflouroacetate salt. Molecular formula of this compound was established as $\mathrm{C}_{20} \mathrm{H}_{15} \mathrm{~N}_{4} \mathrm{O}$ by the use of FABHRMS $\left(\mathrm{MH}^{+} 327.1262\right.$, calculated 327.1246). Several features of the ${ }^{1} \mathrm{H}$ and ${ }^{13} \mathrm{C}$ NMR spectra of (70) were matches with discorhabdins and isobatzellines,<smiles>Cc1c2ccnc3c2c(n1C)C(=O)C(N)=C3Cl</smiles>

69<smiles>O=C1c2[nH]cc3c2C(=NCC3)c2c(-c3c[nH]c4ccccc34)c[nH]c21</smiles> 
suggesting the presence of a pyrroloiminoquinone moiety. The spin system comprising $\delta 13.04$ (br $s, \mathrm{NH} 1), 7.11(d, J=2.5 \mathrm{~Hz}, \mathrm{H} 2), 2.93(t, J=8.0 \mathrm{~Hz}$, H24), 3.78 (br $t, J=8.0 \mathrm{~Hz}, \mathrm{H} 25$ ), and 10.32 (br s, NH6) was established by DQCOSYD and 1-D $1 \mathrm{H}$ difference $\mathrm{NOE}^{70}$ NMR experiments. This spin system was assigned to part of a pyrrolodihydropyridine moiety by HMQC ${ }^{71}$ and $\mathrm{HMBC}^{72}$ NMR experiments. IR absorption at 1662 and $1447 \mathrm{~cm}^{1}$ indicated the presence of an iminoquinone ring which was reconfirmed by ${ }^{13} \mathrm{C} N \mathrm{NMR}$ signals at $\delta 166.28$ (CO) and 156.72 (C7). The connectivities between the pyrrolodihydropyridine system and $\mathrm{C} 7, \mathrm{C} 8$, and $\mathrm{C} 9$ of the iminoquinone ring was established by long range ${ }^{1} \mathrm{H}^{13} \mathrm{C}$ NMR correlations observed for $\mathrm{H} 2$ ( $\delta 120.74)$. The ${ }^{\mathrm{l}} \mathrm{H}$ NMR signals at $\delta 13.41(\mathrm{br} s), 7.28(d, J=2.5 \mathrm{~Hz})$ and ${ }^{13} \mathrm{C}$ NMR signals at $\delta 134.25(\mathrm{~s}), 120.44(\mathrm{~s}), 114.15(\mathrm{~s}), 125.14\left(d,{ }^{1} J_{\mathrm{CH}}=\right.$ $190 \mathrm{~Hz}$ ) confirmed the presence of another 2,3,4 trisubstituted pyrrole ring. Long range ${ }^{1} \mathrm{H}_{-}{ }^{13} \mathrm{C}$ NMR correlations experiment also confirmed this and proved that the pyrrole ring was bound to $\mathrm{C} 11$ and $\mathrm{C} 15$ of the iminoquinone ring. ${ }^{1} \mathrm{H}$ and ${ }^{13} \mathrm{C}$ NMR data were also suggested the presence of a 3-substituted indole moiety $[\delta 11.54$ (br $d, J=2.0 \mathrm{~Hz}), 7.73(d, J=2.0 \mathrm{~Hz}), 7.52(d, J=$ $8.0 \mathrm{~Hz}), 7.49(d, J=8.0 \mathrm{~Hz}), 7.19(\mathrm{dd}, J=8.0,8.0 \mathrm{~Hz}), 7.09(\mathrm{dd}, J=8.0$, $8.0 \mathrm{~Hz}) ;{ }^{13} \mathrm{C}[\delta 105.90(\mathrm{~s}), 112.07(\mathrm{~d}, J=161 \mathrm{~Hz}), 118.86(d, J=161 \mathrm{~Hz})$, $119.66(d, J=161 \mathrm{~Hz}), 121.85(d, J=161 \mathrm{~Hz}), 124.94(d, J=183 \mathrm{~Hz})$, 125.49 (s), $136.76(\mathrm{~s})]$. This was further confirmed by HMQC and HMBC NMR experiments and by comparison with the ${ }^{13} \mathrm{C} N M R$ data reported for the indole-imidazole moiety of topsentin. ${ }^{73}$ Long-range ${ }^{1} \mathrm{H}-{ }^{13} \mathrm{C}$ correlations by HMBC and selective INEPT NMR experiments between $\mathrm{H} 13$ and $\mathrm{C} 16$ established connectivity between the bipyroloiminoquinone moiety and the 3-substituted indole, and confirmed the structure wakayin.

Sources and cytotoxities of many marine pyridoacridines that have been reviewed recently ${ }^{74}$ are summarized in Table 1.

Table 1 Cytotoxic marine pyridoacridines and their sources

\begin{tabular}{|c|c|c|c|}
\hline S. No. & Pyridoacridine & Source & References \\
\hline 1 & Labuanine-A & Biemna fortis sponge (Indonesia) & 75 \\
\hline 2 & Lissoclin-A & Lissoclinum sp. ascidian (Australia) & 76 \\
\hline 3 & Lissoclin-B & Lissoclinum sp. ascidian (Australia) & 76 \\
\hline 4 & Lissoclin-C & Lissoclinum sp. ascidian (Australia) & 76 \\
\hline 5 & Lissoclinidine & Lissoclinum notti ascidian (New Zealand) & 77 \\
\hline 6 & $\begin{array}{l}\text { 9-Aminobenzo } \\
{[b] \text { pyrido }[4,3,} \\
2 \text {-de }]-[1,10]- \\
\text { phenanthrolin- } \\
8(8 \mathrm{H}) \text {-one }\end{array}$ & Biemnafortis sponge (Indonesia) & 75 \\
\hline 7 & Amoamine-A & $\begin{array}{l}\text { Cystodytes sp. ascidian (Arno Atoll, Rep. } \\
\text { Marshall Is.) }\end{array}$ & 76,77 \\
\hline 8 & Amoamine-B & $\begin{array}{l}\text { Cystodytes sp. ascidian (Arno Atoll, Rep. } \\
\text { Marshall Is.) }\end{array}$ & 77,78 \\
\hline
\end{tabular}




\begin{tabular}{|c|c|c|c|}
\hline S. No. & Pyridoacridine & Source & References \\
\hline 9 & Pantherinine & $\begin{array}{l}\text { Aplidium pantherinum ascidian } \\
\text { (S. Australia) }\end{array}$ & 79 \\
\hline 10 & Sagitol & Oceanapia sagittaria sponge (Palau) & 80 \\
\hline 11 & Sebastianines-A & Cystodytes dellechiajei ascidian (Brazil) & 81 \\
\hline 12 & Sebastianines-B & Cystodytes dellechiajei ascidian (Brazil) & 70,81 \\
\hline 13 & Biemnadin & Biemna fortis sponge (Indonesia) & 75 \\
\hline 14 & $\begin{array}{l}\text { 2-Bromoleptocl } \\
\text { inidinone }\end{array}$ & Leptoclinides sp. ascidian (Truk Lagoon) & 82,83 \\
\hline 15 & Meridine & $\begin{array}{l}\text { Amphicarpa meridiana } \text { ascidian } \\
\text { (S. Australia), Leptoctinides sp. sponge } \\
\text { (Truk Lagoon), Cortidum sp. sponge } \\
\text { (Bahamas) }\end{array}$ & 84,85 \\
\hline 16 & $\begin{array}{l}\text { Meridine } \\
\text { regioisomer }\end{array}$ & Biemna fortis sponge (Indonesia) & 75 \\
\hline 17 & $\begin{array}{l}\text { 5-Methoxyneo- } \\
\text { amphimedine }\end{array}$ & $\begin{array}{l}\text { Xestospongia carbonaria, X. cf. } \\
\text { exigua (Indopacific) }\end{array}$ & 86 \\
\hline 18 & Neoamphimedine & $\begin{array}{l}\text { Xestospongia sp. sponge (Philippines) } \\
\text { Xestospongia cf. carbonaria (Micronesia) } \\
\text { Xestospongia c carbonaria, X. cf. exigua } \\
\text { (Indopacific) }\end{array}$ & $\begin{array}{l}86,87 \\
88,89\end{array}$ \\
\hline 19 & $\begin{array}{l}\text { Neoamphimedine- } \\
\text { Y }\end{array}$ & $\begin{array}{l}\text { Xestospongia c carbonaria, X. cf. exigua } \\
\text { (Indopacific) }\end{array}$ & 86 \\
\hline 20 & $\begin{array}{l}\text { Neoamphimedine- } \\
\mathrm{Z}\end{array}$ & $\begin{array}{l}\text { Xestospongia cf. carbonaria, X. cf. exigua } \\
\text { (Indopacific) }\end{array}$ & 86 \\
\hline 21 & Nordercitin & $\begin{array}{l}\text { Stelletta sp. sponge Derdtus sp. sponge } \\
\text { (Bahamas) }\end{array}$ & 90,91 \\
\hline 22 & Stellettamine & Stelletta sp. sponge & 90 \\
\hline 23 & Styelsamine-A & Eusynstyela lateridus ascidian (Indonesia) & 92 \\
\hline 24 & Styelsamine-B & Eusynstyela lateridus ascidian (Indonesia) & $92,93,94$ \\
\hline 25 & Styelsamine-C & Eusynstyela lateridus ascidian (Indonesia) & 92 \\
\hline 26 & Styelsamine-D & Eusynstyela lateridus ascidian (Indonesia) & 92 \\
\hline 27 & Varamine-A & Lissoclinum vareau ascidian (Australia) & 76,95 \\
\hline 28 & Varamine-B & Lissoclinum vareau ascidian (Australia) & 96,95 \\
\hline 29 & Cystodytin-D & Cystodytes delleehiajei ascidian (Okinawa) & 96,97 \\
\hline 30 & Cystodytin-E & Cystodytes dellechiajei ascidian (Okinawa) & 96,97 \\
\hline 31 & Cystodytin-F & Cystodytes delleehiajei ascidian (Okinawa) & 96,97 \\
\hline 32 & Cystodytin-G & Cystodytes delleehiajei ascidian (Okinawa) & 96,97 \\
\hline 33 & Cystodytin-H & Cystodytes delleehiajei ascidian (Okinawa) & 96,97 \\
\hline 34 & Cystodytin-I & Cystodytes delleehiajei ascidian (Okinawa) & 96,97 \\
\hline 35 & Cystodytin-J & $\begin{array}{l}\text { Cystodytes sp. ascidian (Fiji), Lissoclinum } \\
\text { nolli ascidian (New Zealand) }\end{array}$ & $\begin{array}{l}13,77 \\
96,98\end{array}$ \\
\hline 36 & Cystodytin-K & Lissoclinum nolli ascidian (New Zealand) & 77 \\
\hline 37 & Dercitamine & $\begin{array}{l}\text { Stelleta sp. sponge, Dercitus sp. sponge } \\
\text { (Bahamas) }\end{array}$ & 90,99 \\
\hline 38 & Diplamine & $\begin{array}{l}\text { Diplosoma sp. ascidian (Fiji), Cystodytes } \\
\text { sp. ascidian (Fiji), Lissoclinum nolli } \\
\text { ascidian (New Zealand) }\end{array}$ & $\begin{array}{l}13,93 \\
98,100\end{array}$ \\
\hline 39 & Eilatin & $\begin{array}{l}\text { Cystodytes sp. ascidian (Fijian), } \\
\text { Eudistoma sp. ascidian (Eilat) }\end{array}$ & $\begin{array}{l}13,93 \\
101,102\end{array}$ \\
\hline 40 & Isodiplamine & Lissoclinum nolli ascidian (New Zealand) & 77 \\
\hline
\end{tabular}


Total synthesis of many of the alkaloids have been achieved. Synthesis of cystodytin-A and B have been published by Cinfolini et $\mathrm{al}^{103}$ using an efficient intramolecular photochemical nitrene insertion into an aryl substituted dihydroisoquinoline. Three total synthesis of amphimedine have been reported. ${ }^{104106}$ Synthesis of bromoleptoclinidone and ascidemin have also been published. ${ }^{107,108}$ Total synthesis of most of the pyridoacridines given in Table 1 have also been achieved. New pyridoacridine structures provide fertile area for the design and execution of biologically active heterocyclic molecules. ${ }^{109}$ Newer synthetic strategies are emerging for efficient assembly of tetracyclic and pentacyclic ring system.

\section{Biological Activity of Pyridoacridines}

Mostly all of the pyridoacridines discovered so far have shown strong in vitro cytotoxic activity. The activity has been related to the ability of pyridoacridines to intercalate DNA, so inhibit DNA metabolizing enzymes. Pyridoacridines also exhibited antiviral, antimicrobial, insecticidal, fungicidal, and other activities. Some pyridoacridines have also shown excellent antitumor activity in various models, while others have proven too toxic to be useful for clinical purposes. Pyridoacridine alkaloids show in vitro cytotoxicity against cultured tumor cells ( $\mathrm{L} 1210$ murine leukemia, $\mathrm{P}_{388}$, etc.) or antineoplastic activity in whole animal experiments. Dercitin (33) inhibits a variety of cultured cell clones at nanomolar concentrations and shows antitumor activity in mice and modest antiviral activity against Herpes simplex and A58 murine corona virus at micromolar concentration. ${ }^{42}$ Dercitin (33) exhibited strong inhibition of HSV-1 at $5 \delta \mathrm{g} \mathrm{mL}^{+}$with moderate cytotoxicity. It also completely inhibited murine A59 coronavirus at $1 \mu \mathrm{g} \mathrm{mL}{ }^{4}$ with no cytotoxicity. ${ }^{17}$ A thorough study by Burres et al ${ }^{110}$ has shown that dercitin (33) inhibits both DNA and RNA synthesis upto $83 \%$ at $400 \mathrm{nM}$, but protein synthesis is effected to a lesser extent. Dercitin also binds to calf thymus DNA and relaxed supercoiled $\phi \times 174$ DNA at $36 \mathrm{nM}$ and inhibited DNA polymerase and DNase nick translation at $1 \mathrm{nM}$. Collectively these results suggest that inhibition of enzyme activity by dercitin is of secondary importance, and its activity is entirely consistent with potent intercalation of nucleic acids. The activities of dercitin (33) and its analogues have been compared, and the nature of pharmacophores in dercitin responsible for antiviral and antitumor activities has been identified. In contrast to dercitin (33), neoamphimedine (24) is found to be a potent inhibitor of purified mammalian topoisomerase II ( $\mathrm{IC}_{50} 1.3 \mu \mathrm{M}$ ), but not of topoisomerase I. Neoamphimedine (24) is also shown to intercalate DNA with a $\mathrm{K}_{\mathrm{m}}$ of $2.8 \times 10^{5} \mathrm{M}^{4}$ and a binding site size of 1.8 base pairs per molecule of 24 . Interestingly, the isomeric base amphimedine (22), petrosamine (4) and debromopetrosamine (25), had little effect on topoisomerase I or II activity, despite displaying comparable cytoxicity. It is postulated that the cytotoxicity of (24) towards mammalian cells can be explained by DNA damage resulting from native 
topoisomerase II inhibition. However, the other pyridoacridin alkaloids may elicit cytotoxicity through as yet unidentified mechanisms associated with DNA processing. Ascididemin (26) and shermilamine B (40) also inhibited topoisomerase II, albeit at higher concentration ( 75 and $30 \mu \mathrm{M}$, respectively), while shermilamine A (39) and meridine (29) are found inactive. ${ }^{14}$

Benzo[4,5]sampangin and ascididemin possess potent antiviral activity while kuanoniamine A appeared inactive. Benzo[4,5]sampangin showed complete inhibition of HSV-1 at $80 \mu \mathrm{g} \mathrm{mL}^{+}$with no host cell toxicity (BSC-1 green monkey cells). It also displayed activity against polio virus type 1 (partial inhibition at $80 \mu \mathrm{g} \mathrm{mL} \mathrm{m}^{+}$with no detectable cytotoxicity to the Pfizer vaccine strain) and HIV-1 (46\% protection at $0.7 \mu \mathrm{M}$ with host cell toxicity at $10 \mu \mathrm{M}) .{ }^{111}$ Hollow fiber assay and tumor implant assays have been developed for antitumor activity assays to assess the antitumor activity of pyridoacridines. ${ }^{12+15}$ Mainly two of types of the tumor models have been used to assess pyridoacridines. In the first, mouse leukemia cells (P338 cells) are injected into the peritoneum of DBA/2 mice. These mice live for approximately 10 days. The tumor bearing mice are then treated with the test drug, which is administered i.p. and response is measured as increased life span (\%ILS). 2-Bromoleptoclinidinone had an excellent in vitro cytotoxicity, but when tested in xenograft models, proved too toxic to yield significant antitumor responses. ${ }^{116}$ Ascididemin was also tested in vivo at the National Cancer Institute, USA against twelve human tumor cell lines by hollow fiber assay and was shown to exhibited significant activity $(\% \mathrm{~T} / \mathrm{C}<50)$ against six of the cell lines. ${ }^{117}$ In vitro activity of several pyridoacridines on markers of leukemia and tumor growth have been assessed. Dercitin (33) and Kuanoniamine have been evaluated for the cytotoxic acitvity and observed that they are approximately equally potent against a solid human lung cancer line and a mouse leukemia line. ${ }^{118}$

Although wakayin (70) exhibits marginal inhibitory activity toward topoisomerase II $(250 \mu \mathrm{M})$, it showed an interestingly differential cytotoxicity against mammalian cell clones that is indicative of DNA damage or interference with DNA procesisng. ${ }^{68}$ It has been demonstrated that the fluorescence spectrum of kuanoniamine D (44) is quenched upon addition of calf thymus DNA, and the emission wavelength of $534 \mathrm{~nm}$ (excitation at $350 \mathrm{~nm}$ ) changed to 593 $\mathrm{nm}$. Both of these findings are suggestive of alkaloid binding to DNA. The two bay region'hitrogen's in 2-bromoleptoclinidone ( 27 ) is ideally disposed to present two donor nitrogen atoms of a bidentate ligand to metals. Alkaloid (27) forms an octahedral complex with $\mathrm{Ru}$ (II) salts that induces photo activated single strand cleavage of supercoiled PBR 322 DNA under visible light irradiation. ${ }^{119}$ It is interesting to note that cytotoxic cystodytins-A (2) and $\mathrm{B}(\mathbf{6})$ are found to be potent $\mathrm{Ca}^{2+}$ release agents, and stimulated calcium release from the sarcoplasmic reticulum (SR) at 36 and 13 times the potency of caffeine, respectively. ${ }^{16}$ 
Ascididemin, benzo[4,5]sampangine, deazaascididemin were found activity against Escherichia coli, Bacillus subtilis, Candida albicans, and Cladisporium resinae, with an MIC of $0.39 \mu \mathrm{g} \mathrm{mL}^{+}$against $C$. albicans. ${ }^{120}$ Cystodytin was found active against E. coli and Staphylococcus aureus. ${ }^{110}$ Sampangine and several analogues exhibited potent antimicrobial activity against the opportunistic infection organisms C. albicans, Cryptococcus neoformans, Aspergillus fumigatus, and Mycobacterium intracellulare. ${ }^{121}$ Limited information is available in the literature regarding the insecticidal activity of pyridoacridine. ${ }^{122}$ Kuanoniamines were studied extensively using neonatal Spodoptera littoralis larvae and the $50 \%$ lethal concentration $\left(\mathrm{LC}_{50}\right)$ was determined.

\section{Indole Alkaloids}

The majority of marine indole alkaloids are rather simple compounds. However, some of the indole alkaloids carry unique structural features. Bacteria and algae have yielded halogenated simple indoles, while more complicated structures have been isolated from marine snails, sponges, bryozoans, etc. ${ }^{123+26}$ Strong antibacterial and antiyeast activities were associated with the red alga Laurencia brongniartii. ${ }^{123}$ The alga yielded the antibacterial agent (71). The compound has been characterized by its ${ }^{1} \mathrm{H}$ and ${ }^{13} \mathrm{C}$ NMR spectra. The proton at $\mathrm{C} 7$ in (71) exhibits substantial solvent-dependent downfield shift.

Six unique bisindole alkaloids have been isolated from the blue-green alga Rivularia firma exhibiting antiinflammatory activity. The major alkaloid (72) (m.p. $239 z 40{ }^{\circ} \mathrm{C}$ ) is responsible for the antiinflammatory effect. ${ }^{127}$ Sponges have yielded brominated tryptamines, 5,6-dibromotryptamine (73) and $\mathrm{N}_{\mathrm{b}}$-methyl-5,6-dibrmotryptamine (74) are obtained from the sponge Polyfibro spongia australis. The bromoindole derivatives showed in vitro Gram-negative, Gram-positive antibacterial activity, and platelet aggregation inhibitory activity. ${ }^{128}$<smiles>Brc1cc2[nH]c(Br)c(Br)c2cc1Br</smiles>

71

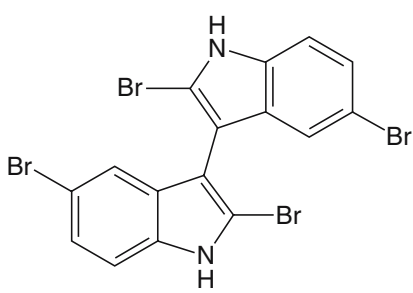

72<smiles>NCCc1c[nH]c2cc(Br)c(Br)cc12</smiles>

73, $\mathrm{R}=\mathrm{H}$

74, $\mathrm{R}=\mathrm{Me}$

\section{Carboline Alkaloids}

Rinehart and others have searched systematically pharmaceutically useful compounds from marine species. ${ }^{129+33}$ Initial efforts have been involved 
surveying of antibacterial and antifungal organisms, with bioassays carried out on shipboard. Later on, focus was shifted to antiviral and cytotoxic compounds. The most active antiviral extract in shipboard testing was obtained from a tunicate subsequently identified as Eudistoma olivaceum, but the extract was surprisingly found inactive in the secondary assay. When the tunicate was recollected, its extracts proved very active in both primary and secondary assay against Herpes simplex and other viruses. The Eudistoma extract yielded eudistomins variously substituted $\beta$-carbolines. All the compounds isolated had antimicrobial or antiviral activity, but the most potent are the tetracyclic eudistomins with the unique oxathiazepine ring (eudistomins C, E, K, L). ${ }^{130+33}$ Their structures are assigned by spectroscopic techniques (high resolution, FABMS, high resolution EIMS, ${ }^{13} \mathrm{C} \mathrm{NMR}, \mathrm{UV}$ ) and by partial synthesis. Eudistomins C, E, K, and L have been assigned the structure (75), (76), (77) and (78), respectively. ${ }^{129,134}$ The stereochemistry of eudistomins (76-78) has been determined by NMR, ${ }^{135}$ and the absolute stereochemistry of eudistomin K (77) was determined by single crystal Xray structural, analysis of its 4-bromobenzyl derivative. ${ }^{136,137}$ A new manzamine related tetrahydro- $\beta$-carboline alkaloid with a methylene bridge between N-2 and N-27 and named eghedin-A was isolated from an Okinawan marine sponge Amphimedon sp. Its structure was determined on the basis of spectroscopic data. The compound exhibited antibacterial activity against Sarcina lutea $(\mathrm{MIC}=2.8 \mathrm{~g} / \mathrm{mL})$, and Corynobacterium xerosis $(5.7 \mathrm{~g} / \mathrm{mL})$ and showed cytotoxicity against murine leukemia L 1210 cells $\left(\mathrm{IC}_{50}=\right.$ $4.4 \mathrm{~g} / \mathrm{mL}) .{ }^{136}$

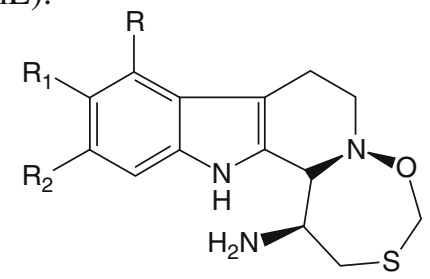

75, R $=H, R_{1}=O H, R_{2}=B r$
76, R $=B r, R_{1}=O H, R_{2}=H$
77, R $=H, R_{1}=H, R_{2}=B r$
78, R $=H, R_{1}=B r, R_{2}=H$

\section{Complex Indole Alkaloids}

A deep water Caribbean sponge Dragmacidon sp. has yielded an alkaloid named dragmacidin (79) which inhibits the growth of several cancer cell lines. ${ }^{138}$ Dragmacidin (79) contains two tryptamine units and an unoxidized piperizene ring which had not been found before in marine natural products. The pacific sponge Hexadella sp. ${ }^{139}$ collected from the coast of British Columbia afforded dragmacidon $\mathrm{A}(\mathbf{8 0})$ another member of the group, exhibits potent cytotoxicity.

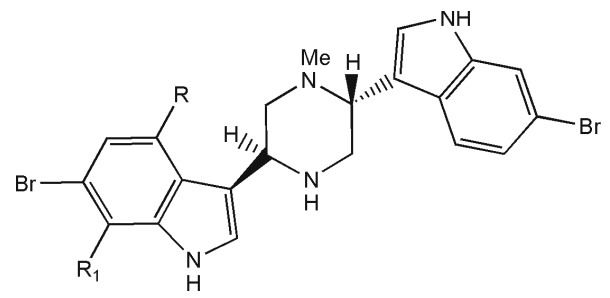

79, $\mathrm{R}=\mathrm{OH}, \mathrm{R}_{1}=\mathrm{Br}$

80, $\mathrm{R}=\mathrm{R}_{1}=\mathrm{H}$ 
Fascaplysin (81), ${ }^{140143}$ a blood red pigment obtained from a Fijian sponge Fascaplysinopsis sp. Fascaplysin (81), exhibits antimicrobial and cytotoxic properties. ${ }^{144}$ Chartelline A (82) a unique $\beta$-lactam indole alkaloid, which exhibits cytotoxicity in vitro against $\mathrm{KB}$, and PS cell lines, has been isolated from a marine bryozoan Chartella papyracea collected in North Britanny waters. ${ }^{145}$ The biosynthesis of this new class of alkaloid appears quite interesting. It will be worth to know whether chartelline-A (82) is a true bryozoan metabolite or produced by some microorganism.

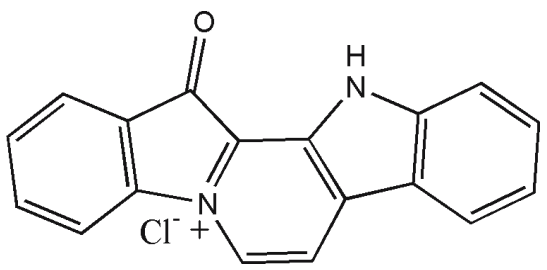

81

Five flustramine derivatives, ${ }^{146149}$ dihydroflustramine-C (83), and its Noxide flustramine-D (84) and its N-oxide and isoflustramine have been isolated from bryozoan Flustra foliaceae ${ }^{146}$ Flustramines are tricyclic indole alkaloids responsible for the antimicrobial activity of the methylene chloride soluble fraction of aqueous methanolic extract of the bryozoan. Oxidation of dihyro flustramine-C (83) and D (84) with m-chloroperbenzoic acid yielded the corresponding $\mathrm{N}$-oxide, $(\mathbf{8 5})$ and $(\mathbf{8 6})$, respectively.<smiles>CC1(C)/C=C\C2=Nc3cc(Br)c(Br)c(Br)c3[C@@]23CC(=O)N3/C=C(/Cl)c2[nH]c(Br)nc21</smiles>

82

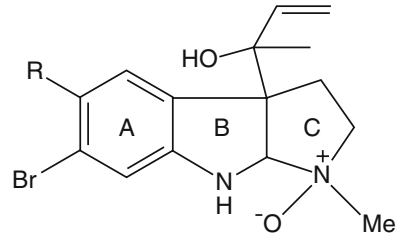

85, $\mathrm{R}=\mathrm{H}$

86, $\mathrm{R}=〉$

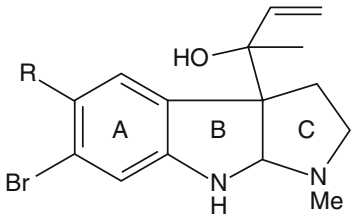

83, $\mathrm{R}=\mathrm{H}$

84, $R=〉$<smiles>Oc1c(Br)cc(Br)cc1-c1[nH]c(Br)c(Br)c1Br</smiles>

87<smiles>Brc1[nH]c(Br)c(Br)c1Br</smiles>

88 


\section{Pyrrole Alkaloids}

Several simple brominated pyrroles have been isolated from marine bacteria and sponge. A highly brominated pyrrole derivative (87) and low molecular weight biologically active compounds have been obtained from a bacterial source. ${ }^{150,151}$ The compound (87) is composed of more than $70 \%$ bromine by weight and is characterized by X-ray crystallographic analysis. ${ }^{152}$ It displays impressive in vitro antibiotic properties against Grampositive bacteria. However, it was found inactive in vivo. It also displayed antitumor activity. The alkaloid (87) has been synthesized. ${ }^{153}$ The purple colored bacterium of the genus Alteromonas ${ }^{154}$ yielded a tetrabromo pyrrole (88) along with other metabolites. The compound (88) displays moderate antimicrobial activity in vitro against Stayphylococcus aureus, Escherichia coli, Pseudomonas aeruginosa and Candida albicans. Number of brominated pyrrole alkaloids have been isolated from sponge Agelas sventres. ${ }^{155157}$ The dichloromethanemethanol extract of this sponge resulted in the isolation of the known alkaloids, oroidin (328 mg), 4,5-dibromopyrrole-2-carboxylic acid (35 mg), hymenidin $(417 \mathrm{mg})$ and new bromopyrrole-derived alkaloid named sventrin $(75 \mathrm{mg})$. The known brominated alkaloids hymenidin, oroidin, and 4,5-dibromopyrrole2-carboxylic acid (89) were characterized by comparison of their spectroscopic data with those reported in the literature. ${ }^{158+60}$ Isotopic cluster of sventrin at $\mathrm{m} / \mathrm{z} 400,402$, and $404[\mathrm{M}+\mathrm{H}]^{+}$in the ratio 1:2:1 in ESI mass spectrum provedd the presence of two bromine atoms. The molecular formula of was determined as $\mathrm{C}_{12} \mathrm{H}_{14} \mathrm{Br}_{2} \mathrm{~N}_{5} \mathrm{O}$ by $\left(\mathrm{m} / z, 401.9565,[\mathrm{MH}]^{+}\right)$, by high resolution FABMS. The ${ }^{1} \mathrm{H}$ and ${ }^{13} \mathrm{C}$ NMR data were in agreement with the proposed molecular formula. The NMR spectra of the base was compared with a oroidin and it was found that it has one less NH signal than oroidin and an additional methyl signal at $3.89 \mathrm{ppm}$ which was assigned as an $\mathrm{N}$-methyl group. The presence of $\mathrm{HMBC}$ correlations from the $N$-methyl group to C2 and $\mathrm{C}-5$, and absence of the pyrrole $\mathrm{NH}$ established the structure of sventrin as $\mathrm{N}$ (pyrrole)-methyl oroidin = sventrin). Dibromo pyrrole carboxylic acid showed in vitro immunosuppressive activity. ${ }^{161}$ The Caribbean colonial tunicate Eudistoma olivaceum has afforded a number of $\beta$-carboline alkaloids. Of these, eudistomin-A (90) has a pyrrole- $\beta$-carboline and eudistomin-G (91) has pyrrolinyl- $\beta$-carboline structures.

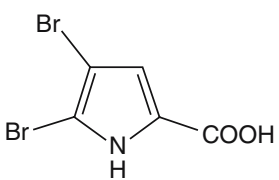

89

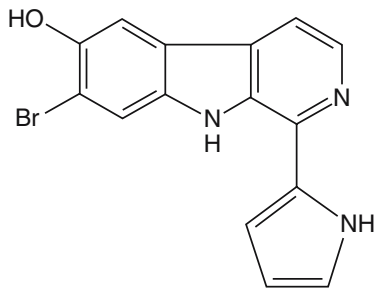

90

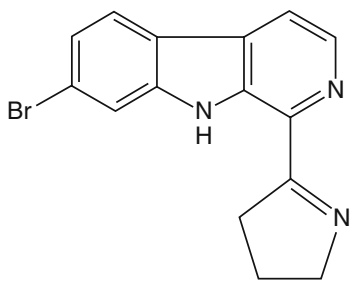

91 
Several other eudistomins have also been isolated from this source. ${ }^{162,163}$ An Okinawan tunicate Eudistoma glaucus has yielded eudistomidin A derivative (92). ${ }^{164}$ The compound (92) exhibits strong calmodulin antagonistic activity, and is the first calmodulin antagonist of marine origin. It is about 15 times more potent than W-7, a well-known calmodulin antagonist.

Eudistomidins-B, C and D have also been obtained from the same tunicate. ${ }^{165,166}$ The absolute configuration of eudistomidin B $(\mathbf{9 3})$ is determined by NMR and CD data, whereas of eudistomidin C (94) is determined by synthesis of 6-methyl-1-10 $(R)$-eudistomidin $\mathrm{C}$. These new $\beta$-carbolines display antileukemic activity. Eudistomidin-B (93) inhibits $\mathrm{Na}^{+}, \mathrm{K}^{+}$ATPase, but activates octomyosin ATPase, whereas eudistomidin C (94) shows calmodulin antagonistic activity. Eudistomidin-D (95) induces $\mathrm{Ca}^{2+}$ release from SR. The New Zealand ascidian Ritterella sigillinoides has afforded, eudistomin $\mathrm{K}$ (96) sulfoxide and shows antiviral activity.<smiles>Oc1cc(Br)cc2c1[nH]c1c(C3=NCCC3)nccc12</smiles>

92<smiles>Cc1ccc(CCC2c3[nH]c4ccc(Br)cc4c3CCN2C)cc1</smiles><smiles>C[C@H](CN(C)C)c1nccc2c1[nH]c1ccc(O)c(Br)c12</smiles>

94

More than sixty bioactive bromopyrroles have been isolated from marine sponges of the genus Agelas. ${ }^{167}$ Most of them are either C11 or C12 oroindine derivatives with exception to latondulin-A ${ }^{168}$ and 4,5-dibromopyrrole-2cabonitirle. ${ }^{169}$ Very recently a fluorescent alkaloid ageladine-A (97) was isolated from marine sponge Agelas nakamurai. ${ }^{170}$ Ageladine-A (97) is the first example of this family which contains 2-amino-imidazolopyridine. ${ }^{170}$ Ageladine-A (97) was isolated from the combined extract of the sponge, and purified by ODS flash chromatography, gel filtration, and ODS HPLC. Repetitive reversed phase HPLC of active fractions afforded ageladine-A<smiles>Oc1ccc2c(c1Br)c1ccncc1n2-c1ccccc1</smiles>

95<smiles>N[C@H]1CSCON2CCc3c([nH]c4cc(Br)ccc34)C12</smiles>

96<smiles>Nc1nc2c(-c3cc(Br)c(Br)[nH]3)nccc2[nH]1</smiles>

97 
(97) as yellow powder. The structure of this novel marine natural product was determined by the use of spectral techniques such as LR, HR-FABMASS, 1D/2D-NMR, ${ }^{13} \mathrm{C}$ NMR. The FABMS spectra showed $(\mathrm{MH})^{+}$clusture at $m / z, 356 / 358 / 360$ in the $1: 2: 1$ ratio. Presence of clusture of peaks in the ratio of 1:2:1 is typical for the presence of two bromine atoms. On the basis of FAB-HRMS and ${ }^{13} \mathrm{C}$ NMR spectral data molecular formula of ageladine-A (97) was established as $\mathrm{C}_{10} \mathrm{H}_{7} \mathrm{~N}_{5} \mathrm{Br}_{2}$ indicating the presence of nine double bonds in the compound. The final structure of this compound was established by using $2 \mathrm{D}$ NMR and ${ }^{13} \mathrm{C}$ NMR spectral data. Ageladine-A (97) showed antiangiogenic activity. ${ }^{170}$

\section{Isoquinoline Alkaloid}

Arai et $\mathrm{al}^{171}$ have published a review on isoquinoline alkaloids of actinomycetes and sponges. The bright blue sponge Reniera sp. has yielded a variety of isoquinoline alkaloids. Of these, renierone (98) exhibits high order of antibacterial activity. ${ }^{172,173}$ Since the sponge contained relatively small quantities of the alkaloids, the possibility of a symbiotic microorganism origin cannot be ruled out. All the alkaloids isolated from the sponge Reniera sp. exhibit antimicrobial activity against selected terrestrial and marine microorganisms. Renierone (98) and N-formyl-1,2-dihydrorenierones (99 and 100) both inhibit cell division in the fertilized sea urchin egg assay. ${ }^{174}$

New dimeric isoquinoline alkaloid Juromycin has been isolated from the skin and mucus of the pacific nudibranch Jorunna funebris. The compound exhibited potent cytotoxicity against various cancer cell lines. ${ }^{175}$ An usual isoquinoline alkaloid imbricatine $(\mathbf{1 0 1})$ has been isolated from the starfish Dermasterias imbricata. ${ }^{176}$ The alkaloid (101) displays significant antineoplastic activity.

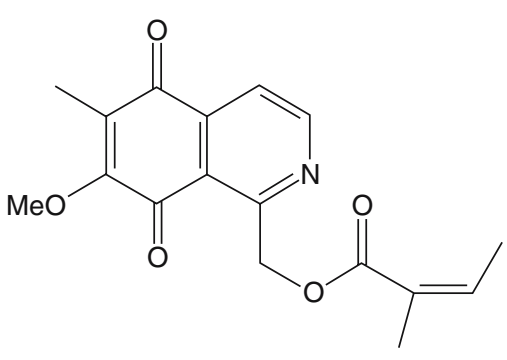

98<smiles>[R]/C(=C/C)C(=O)OCC1C2=C(C=CN1O)C(=O)C(C)=C(OC)C2=O</smiles>

99, $\mathrm{R}=\mathrm{H}$

$100, R=M e$

\section{Miscellaneous Alkaloids}

Halichlorine (102) $)^{177+81}$ and Pinnaic acids (103) ${ }^{182+85}$ two closely related alkaloids were isolated by from the Okinawan bivalve Pinna muricata and the sponge Halichondria okadai Kadota, respectively. Both compounds exhibit antiinflammatory activity, by different mechanisms. Pinnaic acid inhibits cPLA2 in vitro $\left(\mathrm{IC}_{50}=0.2 \mathrm{mM}\right)$ whereas halichlorine is a vascular cell- 


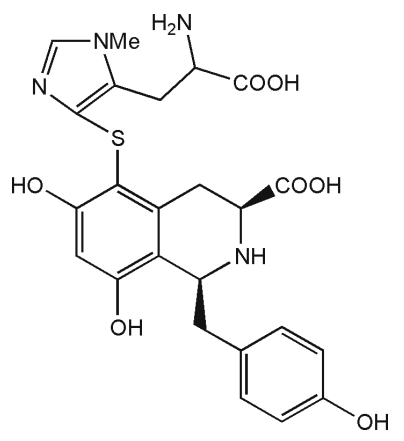

101

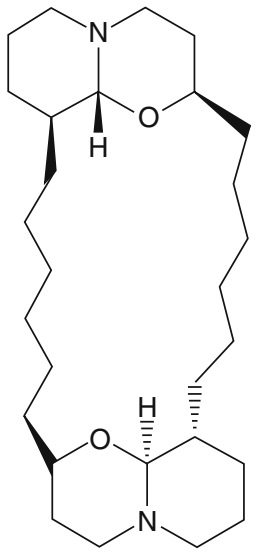

102

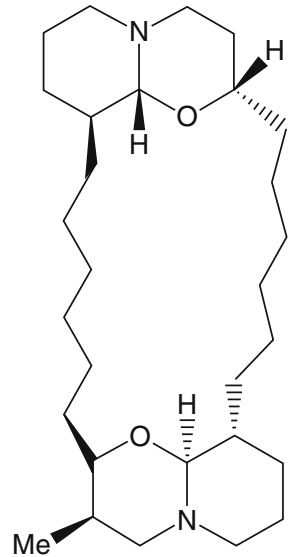

103

adhesionmolecule-1 (VCAM-1) antagonist. Although pinnaic acid and halichlorine inhibit different target proteins, but close examination of these compounds reveals that these alkaloids share a common azaspiro unit. The structure of (102) and (103) was elucidated by detailed spectroscopic analysis. Halichlorine consists of a sterically hindered 15-membered lactone, an azabicyclo [4.4.0] ring, and a [5.6]-spiro ring moiety. Asymmetric syntheses of these novel alkaloids have been achieved recently.

Several bromotyrosine derived alkaloids have been isolated from sponges. Purealin (104) and lipopurealins A-C (105-107) have been obtained from an Okinawan sponge Psammaplysilla purea. ${ }^{186}$<smiles>COC1=C(Br)[C@@H](O)[C@]2(C=C1Br)CC(C(=O)NCCCOc1c(Br)cc(CC(=NO)C(=O)NCCc3c[nH]c(N)n3)cc1Br)=NO2</smiles>

104

Purealin (104) and lipopurealin A and C (105 and 107) exhibit inhibitory activity on $\mathrm{Na}^{+}, \mathrm{K}^{+}$-ATPase. Purealin (104) is the first natural product that was found to activate myosin K. EDTA-ATPase whereas this enzyme activity is inhibited by lipopurealin B (106).

Tunicates selectively accumulate vanadium (or iron) in their specialized blood cells. The tunicate Molgula manhattensis has yielded two tunichromes (108 and 109) which are reported to accumulate the metal. ${ }^{187}$ 
<smiles>[R]NCCCOc1ccc(CC(=NO)C(=O)NCCc2c[nH]c(=N)[nH]2)cc1Br</smiles>

105, $\mathrm{R}=\mathrm{CO}\left(\mathrm{CH}_{2}\right)_{12} \mathrm{CH}_{3}$

106, $\left.\mathrm{R}=\mathrm{CO}\left(\mathrm{CH}_{2}\right)_{11} \mathrm{CH}_{3}\right)_{2}$

107, $\mathrm{R}=\mathrm{CO}\left(\mathrm{CH}_{2}\right)_{14} \mathrm{CH}_{3}$<smiles>[R]c1cc(/C=C/NC(=O)/C(=C/c2cc(O)c(O)c(O)c2)NC(=O)[C@H](N)Cc2cc([R2])c(O)c(O)c2)cc(O)c1O</smiles>

108, $R_{1}=R_{2}=H$

109, $\mathrm{R}_{1}=\mathrm{H}, \mathrm{R}_{2}=\mathrm{OH}$

The sea anemone Sagartia troglodytes ${ }^{188}$ has afforded 1-iminomethyl-3methyl-6-aminomethyl-9H-purine (110) which inhibits the growth of tumors viruses of plant or bacteria. However, its activity is less than 1,2-diaminopurine. The North East Pacific bryozoan Phidolopora pacifica ${ }^{189-192}$ contained desmethylphidolopin (111) which exhibits antimicrobial activity. The Astroides calucularis $^{193}$ collected in the Bay of Naples yielded 2-amino-6-(1R, $\left.2 S\right)$ $\left[1^{\prime}, 2^{\prime}\right.$-dihydroxypropyl]-3-methylpterin-4-one (112). The compound (112), exhibits cell growth inhibitory activity. ${ }^{193}$<smiles></smiles>

110<smiles></smiles>

111<smiles>COc1c(C)c2c(c(OC)c1OC)CCSC2=O</smiles>

112 
A Pyrrolopyrimidine alkaloid rigidin (113) ${ }^{194,195}$ has been obtained from the Okinawan tunicate Eudistoma cf. rigida. ${ }^{194}$ Rigidin (113) displays calmodulin antagonistic activity. ${ }^{194}$ The tunicate Cystodytes sp. (1.6 kg, wet weight) was collected from Ie Island, Okinawa, and was extracted with $\mathrm{MeOH}$ which gave EtOAc soluble materials. Ethyl acetate soluable portion was purified on silica gel coloumn and $\mathrm{C} 18$ column chromatography and C18 HPLC to afford known compounds rigidin (113, $12 \mathrm{mg}, 0.00075 \%)$, iejimalides A-D ${ }^{196,197}$ and dytesinins $A$ and $\mathrm{B}^{198}$ along with unknown alkaloids rigidins $\mathrm{B}$ (114, $4.9 \mathrm{mg}, 0.00031 \%$, wet weight), C (115, $1.3 \mathrm{mg}, 0.00008 \%)$, and $\mathrm{D}\left(\mathbf{1 1 5}, \mathrm{R}_{1}=\mathrm{R}_{2}=\mathrm{OMe}, 0.6 \mathrm{mg}, 0.00004 \%\right)$. Molecular formula of rigidin $\mathrm{B}$ (114) was established as $\mathrm{C}_{20} \mathrm{H}_{16} \mathrm{~N}_{3} \mathrm{O}_{6}$ by HR-FABMS [m/z 394.1029 $\left.(\mathrm{M}+\mathrm{H})^{+}\right]$which was larger than that of rigidin $(\mathbf{1 1 3})$ by a $\mathrm{OCH}_{2}$ unit. Absorption bands at 3420 and $1666 \mathrm{~cm}^{+}$in the IR spectrum indicated the presence of $\mathrm{OH}, \mathrm{NH}$ and carbonyl group(s), respectively. Presence of conjugated phenol chromophore was confirmed by the UV absorptions at 364 ( $\varepsilon$ 9400), 319 (ع 9600), 304 (sh), 278 (ع 13200), 236 (sh), and $206 \mathrm{~nm}$ (ع 31400). Out of 13 proton signals in the ${ }^{1} \mathrm{H}$ NMR spectrum of (114), five of were $\mathrm{D}_{2} \mathrm{O}$ exchangeable, and the others were due to seven methines and one methoxy group. In the ${ }^{13} \mathrm{C}$ NMR spectrum, all 19 carbon resonances except that of a methoxy carbon ( $\delta$ 55.19) were observed between $\delta 95$ and $190 .{ }^{1}{ }^{1}-{ }^{1} \mathrm{H}$ COSY experiments confirmed presence of 1,4-di and 1,3,4-trisubstituted benzene rings. ${ }^{1} \mathrm{H}^{13}{ }^{13} \mathrm{C}$ HMBC correlations for $\mathrm{H}-9$ and $\mathrm{H}-13$ to $\mathrm{C}-11, \mathrm{H}-10$ and $\mathrm{H}-12$ to $\mathrm{C}-8$, and $\mathrm{OH}-11$ to $\mathrm{C}-10, \mathrm{C}-11$, and $\mathrm{C}-12$ indicated the presence of an 11-hydroxyphenyl group (C-8-C-13). On the other hand, the existence of an 18-hydroxy-17-methoxybenzoyl moiety (C14-C20) was inferred by ${ }^{1} \mathrm{H}-{ }^{13} \mathrm{C}$ HMBC correlations for $\mathrm{H}-16$ to $\mathrm{C}-14, \mathrm{C}-18$, and $\mathrm{C}-20, \mathrm{H}-19$ to $\mathrm{C}-15$ and $\mathrm{C}-17, \mathrm{H}-20$ to $\mathrm{C}-18,17-\mathrm{OCH} 3$ to $\mathrm{C}-17$, and $18-\mathrm{OH}$ to $\mathrm{C}-17, \mathrm{C}-18$, and C-19. A pyrrolo[2,3-d]pyrimidine-2,4-dione core of (114) was assigned by detailed analysis of the ${ }^{1} \mathrm{H}_{-}{ }^{13} \mathrm{C}$ HMBC and ${ }^{1} \mathrm{H}_{-}-{ }^{15} \mathrm{~N}$ HSQC spectra and NOE experiments. The molecular formula of rigidin $\mathrm{C}$ (115) was established as $\mathrm{C}_{20} \mathrm{H}_{16} \mathrm{~N}_{3} \mathrm{O}_{6}$ and rigidin $\mathrm{D}$ as $\mathrm{C}_{20} \mathrm{H}_{18} \mathrm{~N}_{3} \mathrm{O}_{7}$ by HRFABMS data. ${ }^{199}$

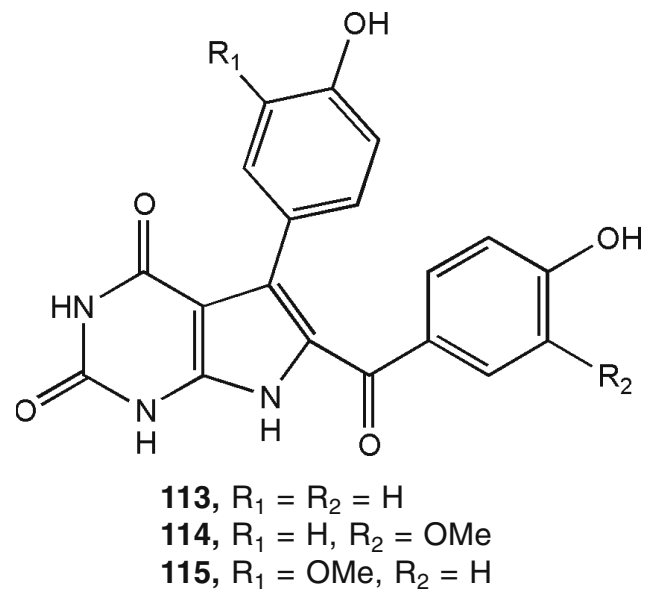


Zoanthamine (116), ${ }^{200 z 03}$ zoanthenamine (117), ${ }^{204}$ zoanthamide (118), ${ }^{204}$ deoxyzoanthanamine (119) $)^{205}$ and zoanthaminone ${ }^{206}$ a new class of alkaloids have been isolated from a new species of colonial zoanthial of the genus Zoanthus collected from the Bay of Bengal. The structure of zoanthamine (116) has been determined by X-ray crystallographic analysis. ${ }^{200}$

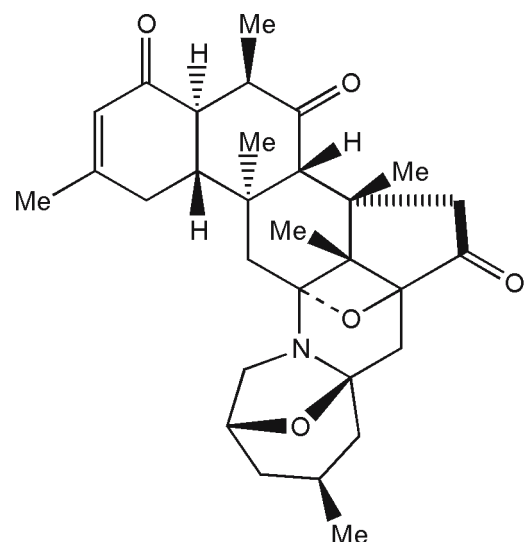

116

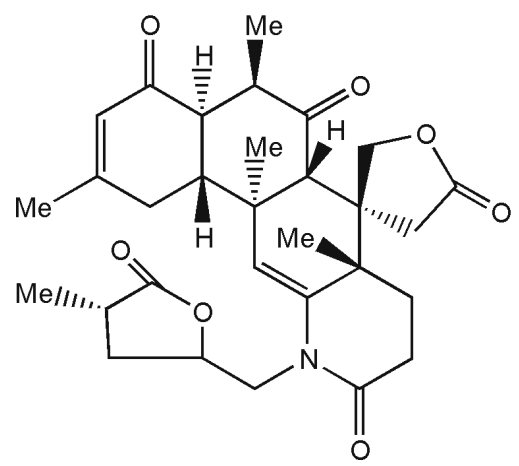

118

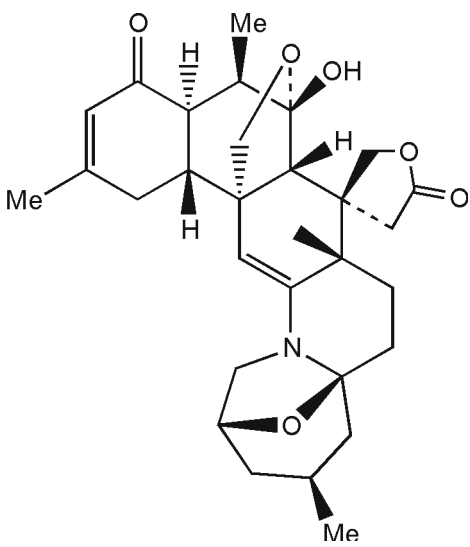

117

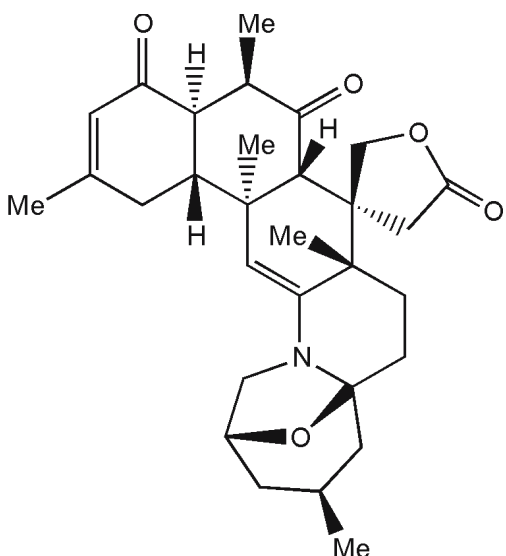

119

The alkaloids (116-119) display inhibitory activity in the phorbol acetate (PMA)-induced mouse ear inflammatory assay as well as analgesic activity. The biosynthesis of these alkaloid is very fascinating and the studies will be rewarding. The marine worm Cephalodiscus gilchristi collected in the Indian Ocean has afforded cephalostatins which were powerful cell growth inhibitory substances against PS cell lines. ${ }^{207213}$ The structure of cephalostatin I (120) has been determined by X-ray analysis. It is suggested that cephalostatins could be formed in nature by condensation of 2-amino-3-oxo-steroid units. The two steroidal units are connected by a pyrazine ring. 


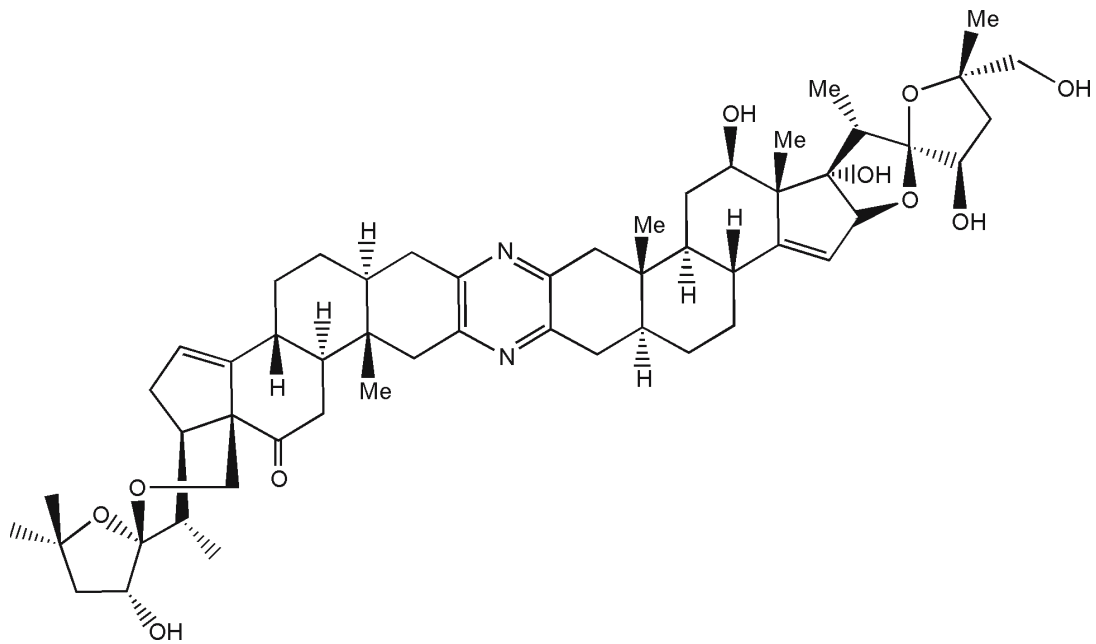

120

Extract of the Okinawan tunicate Pseudodistoma kanoko yielded the anti neoplastic piperine alkaloids pseudodistomin A (121) and B (122) which displayed calmodulin antagonistic activity. ${ }^{214}$ Pseudodistomins are the first piperidine alkaloids found in marine organisms. The Fijian sponge Niphates sp. has afforded the pyridine alkaloids, niphatynes A and B. ${ }^{215}$

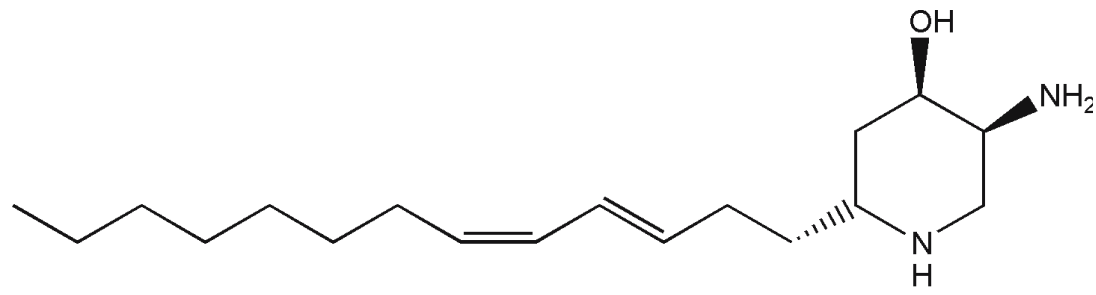

121

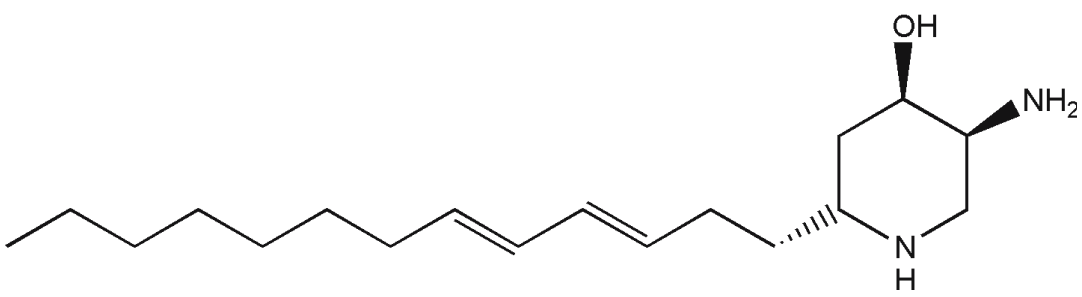

122

Aplysepine (123) ${ }^{216}$ the first 1,4-benzo-diazepine alkaloid of marine origin was isolated from the sea hare Aplysia kurodi. The structure of aplysepine was elucidated on the basis of the spectral data. The new Guinea shell-less mollusk Dolabella auricularia was found to contain a series of green-blue 
chlorins. One of these compounds was found to be the nickel chelat tunichlorin (124) which was isolated previously only from the caribbean tunicate Trididemnum solidum. Discovery of tunichlorin (124) in sea hare suggested that its occurrence is algae consuming marine animals may be more common than earlier realized. It is suggested that it may have a role in electron transfer or other metabolic process in mullusc. ${ }^{217}$ Three imidazole alkaloids, leucettamines A and B, and leucettramidine were isolated from the Palawan sponge Leucetta microraphis and their structures were elucidated on the basis of extensive spectral analyses. Leucettamine A showed potent leukotriene B4 receptor binding activity $\left(K_{\mathrm{i}}=1.3 \mathrm{M}\right){ }^{218}$

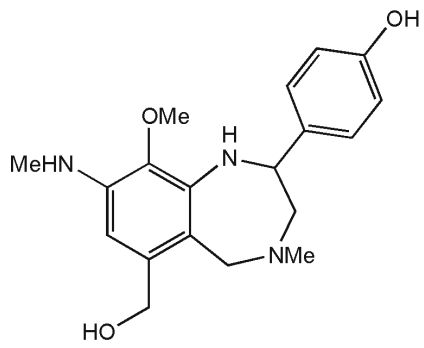

123

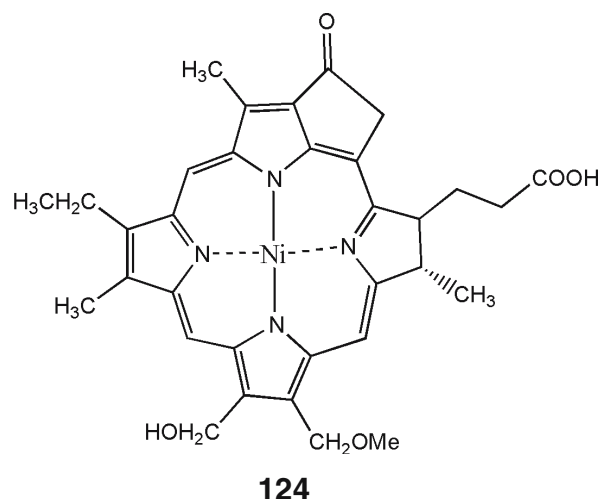

124

Hamacanthin was isolated from a new deep water sponge, Hamacantha sp. The hamacanthins were found to be the growth inhibitors of Candida albicans and Cryptococcus neobormans. ${ }^{219222}$ The major metabolite of the Philippine sponge Oceanapia sp. was the antimicrobial alkaloid oceanapamine (125) which was isolated a a trifluoroacetate salt. The structure and absolute configuration of oceanapamine were determined by the spectroscopic data. The compound showed antimicrobial activity, it inhibited B. subtitis and E. coli at $25 \mathrm{~g} / \mathrm{disk}, S$. aureus and C. albicans at $50 \mathrm{~g} / \mathrm{disk}$ and $P$. aeruginosa at $100 \mathrm{~g} /$ disk. ${ }^{223}$ Pyrrolo[4,3,2-de]quinolines and pyrido[4,3,2-mn]acridine were of major interest as metabolites in sponge and ascidians. Many of these compounds had generated interest both as challenging problems for structural elucidation and synthesis as well as for their cytotoxicity. The principal structural feature of these alkaloids was the core of a planar iminoquinone moiety which tercalate into DNA and cleave the DNA double helix or inhibit

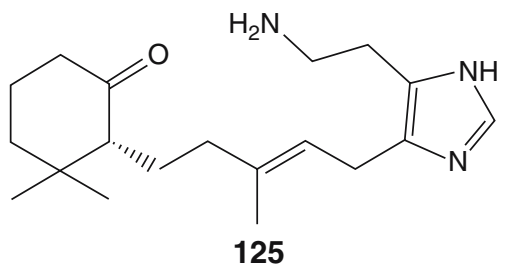


the action of topoisomerase II. Of the makaluvamines, makaluvamines A and $\mathrm{F}$ were the most cytotoxic to the HCT 116 cell line. They were also the most potent inhibitors of topoisomerase II. Both makaluvamines A and $\mathrm{C}$ decreased tumor size in a solid human tumor model. The new member of the pyrrolo[4,3,2-de]quinolines, and pyrido[4,3,2-mn]acridine such as veitamine, discorhabdin $\mathrm{G}$, and epinartins were reported. ${ }^{12}$

Biard et $\mathrm{al}^{224}$ reported the isolation and structure elucidation of a marine alkaloid lepadiformine (126) from the marine tunicate Clavelina lepadiformis ${ }^{224}$ in 1994 and later from C. moluccensis. ${ }^{225}$ Lepadiformine exhibited cytotoxic activity against the various tumor cell lines. Recently, it was found that lepadiformine is very active in vivo and in vitro in the cardiovascular system. ${ }^{225}$ Structure of lepadiformine was determined on the basis of extensive spectral analysis. Recently, Kibayashi et al ${ }^{226,227}$ reported the total synthesis of (-)-lepadiformine.

Asmarines A (127) and B (128) were isolated from the ethyl acetate extract of marine sponge Raspailia sp. collected from Red Sea marine invertebrates. ${ }^{228}$ These alkaoilds exhibited potent cytotoxic activity against four human cancer cell lines. ${ }^{229}$ The structure of asmarine A was ascertained by an X-ray diffraction analysis. ${ }^{229}$ Recently total synthesis of these alkaloids have been achieved. ${ }^{230}$

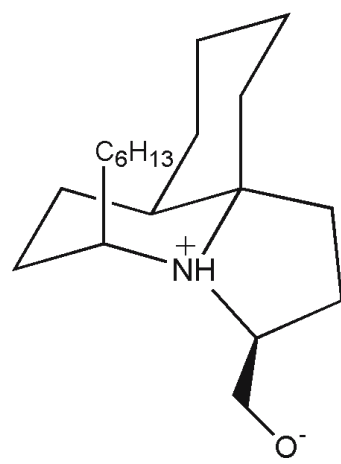

126

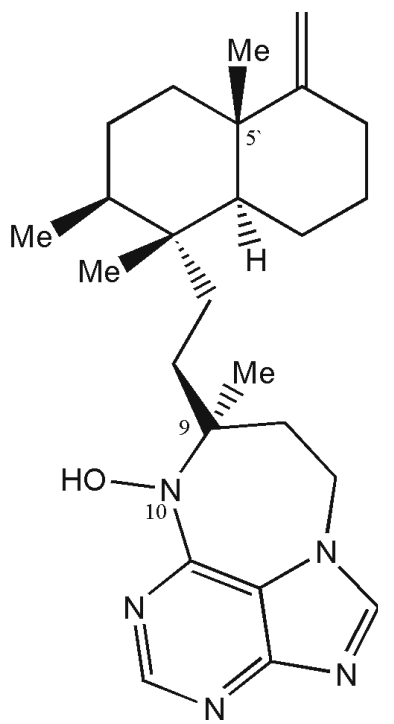

127

128 (5’ Epi)

Recently Berlinck et al ${ }^{231}$ had reported the isolation and structural elucidation of marine alkaloid ingenamine $\mathrm{G}(\mathbf{1 2 9})$, and mixture of new cyclostellettamines G, H, I, K and L (130-134) from marine sponge Pachychalina sp. The methanolic extract of the ingenamine $\mathrm{G}$ displayed cytotoxic activity against 


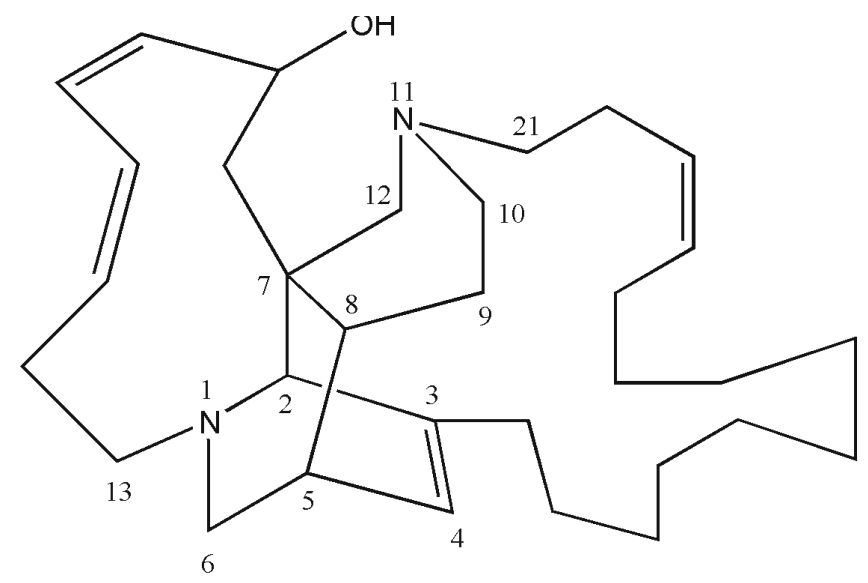

129

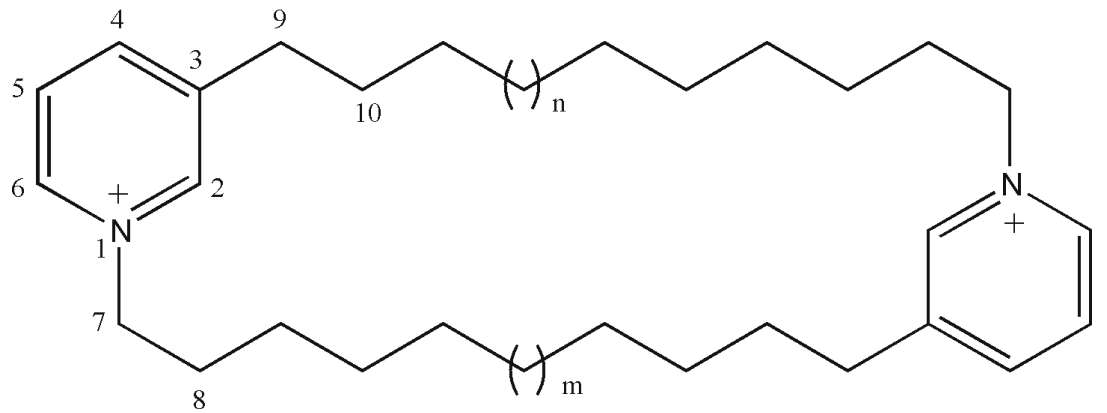

$$
\begin{aligned}
& \text { 130, } m=2, n=3 \\
& \text { 131, } m=1, n=3 \\
& \text { 132, } m=1, n=4 \\
& \text { 133, } m=1, n=5 \\
& 134, m=2, n=5
\end{aligned}
$$

HCT-8 (colon), B16 (leukemia), and MCF-7 (breast) cancer cell lines, antibacterial activity against Staphylococcus aureus (ATCC 25923), Escherichia coli (ATCC 25922), and four oxacilin-resistant S. aureus strains, and antimycobacterial activity against Mycobacterium tuberculosis H37Rv. The sponge, $(2.0 \mathrm{~kg})$ was extracted with $\mathrm{EtOH}$. Both $\mathrm{EtOH}$ and $\mathrm{MeOH}$ extracts were subjected to solvent partition with EtOAc and with n-BuOH. EtOAc extract after evaporation was dissolved in $\mathrm{MeOH}-\mathrm{H}_{2} \mathrm{O}(9: 1)$ and partitioned with hexane. The $90 \%$ of the solvent was evaporated, and the residue thus obtained was dissolved in $\mathrm{CH}_{2} \mathrm{Cl}_{2}-0.5 \mathrm{~N} \mathrm{HCl}$. Compound (129) was isolated as an optically active glassy solid after repeated chromatographic separations. Molecular formula of the compound was determined as $\mathrm{C}_{32} \mathrm{H}_{51} \mathrm{~N}_{2} \mathrm{O}$ by its HR-FABMS $(\mathrm{m} / \mathrm{z}$ 479.40007, calcd 479.40014). The molecular formula indicated the presence of nine degrees of unsaturation. By the use of ${ }^{1} \mathrm{H}$ 
$\mathrm{NMR}$, and ${ }^{13} \mathrm{C}$ NMR data it was concluded that this compound must have five rings. Additionally, NMR analysis indicated the presence of three sp3 methines $(\delta 62.1,40.4$, and 37.6), one sp3 $(\delta 44.6)$ and one sp2 $(\delta 144.5)$ quaternary carbons, and five typical nitrogen-substituted methylene resonances $(\delta 50.6,51.2,56.3,58.0,59.4)$, which suggested an ingenamine-type skeleton for (129). Comparison of the ${ }^{13} \mathrm{C}$ NMR data of (129) with related alkaloids indicated the presence of a tricyclic central core. Extensive analysis of NMR spectra including HSQC, HMBC, ${ }^{1} \mathrm{H}-{ }^{1} \mathrm{H}$ COSY, HSQCTOCSY, and NOESY confirmed the structure of these mairne alkaloids. Similarly, structure of other alkaloids (130-134) have been confirmed.

\section{Concluding Remarks}

The field of marine alkaloids is firmly established and rapidly expanding. Over 75 pyridoacridine alkaloids have been isolated from marine sponges, tunicates and molluscs and characterized. There is little doubt that their number will increase in future. Marine alkaloids, particularly brominated or chlorinated ones, do have distinct features as compared to alkaloids from terrestrial sources. There are ample circumstantial evidences which suggest that some of the marine alkaloids are metabolites of an associated flora. Since the origin of a number of alkaloids is uncertain, the attempts of construction of chemotaxonomical system based on secondary metabolites analysis must be viewed with caution. Although quite a number of marine alkaloids display high order of antineoplastic and antiviral activity, a drug from this source is still very far. However, studies conducted on marine alkaloids have enriched basic organic chemistry and the biological activities have widened the vision of chemists and biologists. The biological effects of bioactive marine alkaloids have expanded greatly our knowledge of several basic phenomena in biology. The new structures have provided fertile area for design and synthesis. The biosynthesis of bioactive marine alkaloids is fascinating and remains unexplored.

\section{References}

1. Christophersen, C. In: Alkaloids: Chemistry and Pharmacology; (edited by A. Brossi), Academic Press, Orlando, 1985, 24, p. 25.

2. Fenical, W. In: Alkaloids; Chemical and Biological Perceptives: Vol. 4 (edited by S. W. Pelletier) John Wiley and Sons, N.Y. 1986, p. 275.

3. Kobayashi, J.; Ishibashi, M. In: Alkaloids: Chemistry and Pharmacology, (edited by A. Brossi and G. A. Cordell), Academic Press, San Diego, 1992, 41, p. 41.

4. Wrobel, J.; Wojtassiewicz, K. In: Alkaloids: Chemistry and Pharmacology, (edited by J. A. Cardell), Academic Press., San Diego. 1992, 42, p. 249.

5. Delfourne, E.; Kiss, R.; Le Corre, L.; Merza, J.; Bastide, J. Frydman, A.; Darro, F. Bioorg. Med. Chem. 2003, 11, 4351.

6. Delfourne, E.; Kiss, R.; Le Corre, L.; Dujols, F.; Bastide, J. Collignon, F.; Lesur, B.; Frydman, A.; Darro, F. J. Med. Chem. 2003, 46, 3536. 
7. Copp, B. R.; Kayser, O.; Brun, R.; Kiderlen, A.F. Planta Med. 2003, 69, 527.

8. Thale, Z.; Johnson, T.; Tenney, K.; Wenzel, P. J.; Lobkovsky, E.; Clardy, J.; Media, J.; Pietraszkiewicz, H.; Valeriote, F. A.; Crews, P. J. Org. Chem. 2002, 67, 9384.

9. Nilar, N.; Sidebottom, P. J.; Carte, B. K.; Butler, M. S. J. Nat. Prod. 2002, 65, 1198.

10. Torres, Y. R.; Bugni, T. S.; Berlinck, R. G. S.; Ireland, C. M.; Magalhaes, A.; Ferreira, A. G.; Moreira, D.; Rocha, R. J. Org. Chem. 2002, 67, 5429.

11. Delfourne, E.; Darro, F.; Bontemps-Subielos, N.; Decaestecker, C.; Bastide, J.; Frydman, A.; Kiss, R. J. Med. Chem. 2001, 44, 3275.

12. Ding, Q.; Chichak, K.; Lown, J. W. Curr. Med. Chem. 1999, 6, 1.

13. McDonald, L. A.; Eldredge, G. S.; Barrows, L. R.; Ireland, C. M. J. Med. Chem. 1994, 37, 3819.

14. Schmitz, F. J.; Deguzman, F. S.; Hossain, M. B.; Vanderhelm, D. J. Org. Chem. 1991, 56, 804.

15. Taraporewala, I. B.; Cessac, J. W.; Chanh, T. C.; Delgado, A. V.; Schinazi, R. F. J. Med. Chem. 1992, 35, 2744.

16. Kobayashi, J.; Cheng, J.; Walchi, M. R.; Nakamura, H.; Hirata, Y.; Sasaki, T.; Ohizumi, Y. J. Org. Chem. 1988, 53, 1800.

17. Delfourne, E.; Bastide, J. Med. Res. Rev. 2003, 23, 234.

18. Molinski, T. F. Chem. Rev. 1993, 93, 1825.

19. Reich, S.; Buhrer, C.; Henze, G.; Ohlendorf, D.; Mesche, M.; Sinha, P.; Kage, A.; Muller, C.; Vetter, B.; Kulozik, A. E. Blood 2000, 96, 3357.

20. Domenica Cappellini, M.; Graziadei, G.; Ciceri, L.; Comino, A.; Bianchi, P.; Porcella, A.; Fiorelli, G. Blood Cells Mol. Dis. 2000, 26, 105.

21. Gleave, M. E.; Sato, N.; Sadar, M.; Yago, V.; Bruchovsky, N.; Sullivan, L. J. Cell Biochem. 1998, 69, 271.

22. Saleh, A. W. Jr.; van Goethem, A.; Jansen, R.; Velvis, H. J.; Gu, L. H, Huisman, T. H. Am. J. Hematol. 1995, 49, 244.

23. Ding, Q.; Chichak, K.; Lown, J. W. Curr. Med. Chem. 1999, 6, 1.

24. Kobayashi, J.; Tsuda, M.; Tanabe, A.; Ishibashi, M.; Cheng, J. F.; Yamamura, S.; Sasaki, T. J. Nat. Prod. 1991, 54, 1634.

25. Molinski, T. F.; Ireland, C. M. J. Org. Chem. 1989, 54, 5331.

26. (a) Davidson, B. S.; Molinski, T. F.; Barrows, L. R.; Ireland, C. M. J. Am. Chem. Soc. 1991, 113, 4709. (b) Molinski, T. F.; Ireland, C. M. J. Org. Chem. 1989, 54, 4256.

27. Charyulu, G. A.; McKee, T. C.; Ireland, C. M. Tetrahedron Lett. 1989, $30,4201$.

28. Lederer, E.; Tessier, G.; Huttrer, C. Bull. Soc. Chim. Fr. 1940, 7, 608.

29. Barbier, M. Naturwissenschaften 1982, 69, 341.

30. Cimino, G.; Crispino, A.; De Rosa, S.; De Stefano, S.; Gavagnin, M.; Sodano, G. Tetrahedron 1987, 43, 4032.

31. Schmitz, F. J.; Agarwal, S. K.; Gunasekera, S. P.; Schmidt, P. G.; Shooley, J. N. J. Am. Chem. Soc. 1983, 105, 4835.

32. Bax, A.; Freeman, R.; Kempsell, S. P. J. Am. Chem. Soc. 1980, 102, 4849.

33. Bax, A.; Freeman, R.; Frenklel, T. A.; Levitt, M. H. J. Magn. Reso. 1981, 43, 478.

34. Marecl, T. H.; Freeman, R. J. Magn. Res. 1982, 48, 158.

35. Kobayashi, J.; Cheng, J.; Nakamura, H.; Ohlzumi, Y.; Hirata, Y.; Sasaki, T.; Ohta, T.; Nozoe, S. Tetrahedron Lett. 1988, 29, 1177.

36. Delfourne, E.; Kiss, R.; Le Corre, L.; Dujols, F.; Bastide, J.; Collignon, F.; Lesur, B.; Frydman, A.; Darro, F. Bioorg. Med. Chem. 2004, 12, 3987.

37. Bloor, S. J.; Schmitz, F. J. J. Am. Chem. Soc. 1987, 109, 6134.

38. De Guzman, F. S.; Schmitz, F. J. Tetrahedron Lett. 1989, 30, 1069. 
39. Bax, A.; Feretti, J. A.; Nashed, N.; Jerina, D. M. J. Org. Chem. 1985, 50, 3029.

40. McCarthy, P. J.; Pits, T. P.; Gunawardana, G. P.; Kelly-Borges, M.; Pompon, S. J. Nat. Prod. 1992, 55, 1664.

41. Molinski, T. F.; Fahy, E.; Faulkner, D. J.; Van Duyne, G. D.; Clardy, J. J. Org. Chem. 1988, 53, 1340.

42. Gunawardana, G. P.; Kohmoto, S.; Gunasekera, S. P.; McConnell, O. J.; Koehn, F. E. J. Am. Chem. Soc. 1988, 110, 4356.

43. Carroll, A. R.; Scheuer, P. J. J. Org. Chem. 1990, 55, 4426.

44. Gunawardana, G. P.; Kohmoto, S.; Burres, N. S.; Tetrahedron Lett. 1989, 30, 4359.

45. Burres, N. S.; Sazesh, S.; Gunawardana, G. P.; Clement, J. J. Cancer Res. 1989, 49, 5267.

46. Cooray, N. M.; Scheuer, P. J. J. Org Chem. 1988, 53, 4619.

47. Townsend, N. O.; Jackson, Y. A. Org. Biomol. Chem. 2003, 1, 3557.

48. Koren-Goldshlager, G.; Aknin, M.; Kashman, Y. J. Nat. Prod. 2000, 63, 830.

49. Carroll, A. R.; Cooray, N. M.; Poiner, A.; Scheuer, P. J. J. Org. Chem. 1989, 54, 4231.

50. Rudi, A.; Benayahu, Y.; Goldberg, I.; Kashman, Y. Tetrahedron Lett. 1989, 29, 3861.

51. Rudi, A.; Kashman, Y. J. Org. Chem. 1989, 54, 5331.

52. He, H. H.; Sakemi, S.; Burres, N.; McCarthy, P. J. Org. Chem. 1991, 6, 5369.

53. Inman, W. D.; O'Neill; Johnson, M.; Crews, P. J. Am. Chem. Soc. 1990, 112, 1.

54. Ford, P. W.; Davidson, B. S. J. Nat. Prod. 1997, 60, 1051.

55. Smith, C. J.; Venables, D. A.; Hopmann, C.; Salomon, C. E.; Jompa, J.; Tahir, A.; Faulkner, D. J.; Ireland, C. M. J. Nat. Prod. 1997, 60, 1048.

56. West, R. R.; Mayne, C. L.; Ireland, C. M.; Brinen, L. S.; Clardy, J. Tetrahedron Lett. 1990, 31, 3271.

57. Zabriskie, T. M.; Mayne, C. L.; Ireland, C. M. J. Am. Chem. Soc. 1988, 110, 7919.

58. Cheng, J. F.; Ohizumi, Y.; Walchli, M. R.; Nakamura, H.; Hirata, Y.; Sasaki, T.; Kobayashi, J. J. Org. Chem. 1988, 53, 4621.

59. Perry, N. B.; Blunt, J. W.; Munro, M. H. G. Tetrahedron 1988, 44, 1727.

60. Perry, N. B.; Blunt, J. W.; McCombs, J. D.; Munro, M. H. G. J. Org. Chem. 1986, $51,5478$.

61. Reyes, F.; Martin, R.; Rueda, A.; Fernandez, R.; Montalvo, D.; Gomez, C.; SanchezPuelles, J. M. J. Nat. Prod. 2004, 67, 463.

62. Gunasekera, S. P.; Zuleta, I. A.; Longley, R. E.; Wright, A. E.; Pomponi, S. A. J. Nat. Prod. 2003, 66, 1615.

63. Tohma, H.; Harayama, Y.; Hashizume, M.; Iwata, M.; Egi, M.; Kita, Y. Angew. Chem. Int. Ed. Engl. 2002, 41, 348.

64. Aubart, K. M.; Heathcock, C. H. J. Org. Chem. 1999, 64, 16.

65. Perry, N. B.; Blunt, J. W.; Munro, M. H. G.; Higa, T.; Sakai, R. J. Org. Chem. 1988, 53, 4127.

66. Sakemi, S.; Sun, H. H.; Jefford, C. W.; Bernardinelli, G. Tetrahedron Lett. 1989, 30, 2517.

67. Sun, H. H.; Sakemi, S.; Burres, N.; McCarthy, P. J. Org. Chem. 1990, 55, 4964.

68. Copp, B. R.; Ireland, C. M.; Barrows, L. R. J. Org. Chem. 1991, 56, 4596.

69. Kokoshka, J. M.; Capson, T. L.; Holden, J. A.; Ireland, C. M.; Barrows, L. R. Anticancer Drugs 1996, 7, 758.

70. Kinns, M.; Sanders, J. K. M. J. Magn. Res. 1984, 56, 518.

71. Summers, M. F.; Marzilli, L. G.; Bax, A. J. Am. Chem. Soc. 1986, 108, 4285.

72. Bax, A,; Summere, M. F. J. Am. Chem. Soc. 1986, 108, 2093. 
73. Tsujii, S.; Rinehart, K. L.; Gunasekera, S. P.; Kashman, Y.; Croee, S. S.; Lui, M. S.; Pomponi, S. A,; Diaz, M. C. J. Org. Chem. 1988, 53, 5446.

74. Marshall, K. M.; Barrows, L. R. Nat. Prod. Rep. 2004, 21, 731.

75. Aoki, S.; Wei, H.; Matsui, K.; Rachmat R.; Kobayashi, M. Bioorg. Med. Chem. 2003, 11, 1969.

76. Plubrukarn, A.; Davidson, B. S. J. Org. Chem. 1998, 63, 1657.

77. Appleton, D. R.; Pearce, A. N.; Lambert, G.; Babcock R. C.; Copp, B. R. Tetrahedron 2002, 58, 9779.

78. Schmitz, F. J.; Agarwal, S. K.; Gunasekera, S. P.; Schmidt, P. G.; Shoolery, J. N. J. Am. Chem. Soc. 1983, 105, 4835.

79. Kim, J.; Pordesimo, E. O.; Toth, S. I.; Schmitz, F. J. J. Nat. Prod. 1993, 56, 1813.

80. Salomon, C. E.; Faulkner, D. J. Tetrahedron Lett. 1996, 37, 9147.

81. Jha, R. K.; Zi-rong, X. Mar. Drugs 2004, 2, 123.

82. Lindsay, B. S.; Oliver, A. G.; Rickard, C. E. F.; Brent R. Copp, B. R. Journal Chem. Crystallogr. 1998, 28, 645.

83. Schmitz, F. J.; DeGuzman, F. S.; Hossain, M. B.; van derivative Helm, D. J. Org. Chem. 1991, 56, 804.

84. Schmitz, F. J. Pure Appl. Chem. 1990, 62, 1993.

85. Schmitz, F. J.; DeGuzman, F. S.; Choi, Y. H.; Hossain, M. B.; Rizvi, S. K.; van derivative Helm, D. Pure \& Appl. Chem. 1990, 62, 1393.

86. Thale, Z.; Johnson, T.; Tenney, K.; Wenzel, P. J.; Lobkovsky, E.; Clardy, J.; Media, J.; Pietraszkiewicz, H.; Valeriote, F. A.; Crews, P. J. Org. Chem. 2002, 67, 9384

87. Marshall, K. M.; Matsumoto, S. S.; Holden, J. A.; Concepcion, G. P.; Tasdemir, D.; Ireland, C. M.; Barrows, L. R. Biochem. Pharm. 2003, 66, 447.

88. Tasdemir, D.; Marshall, K. M.; Mangalindan, G. C.; Concepcion, G. P.; Barrows, L. R.; Harper, M. K.; Ireland, C. M. J. Org. Chem. 2001, 66, 3246.

89. de Guzman, F. S.; Carte, B.; Troupe, N.; Faulkner, D. J.; Harper, M. K.; Concepcion, G. P.; Mangalindan, G. C.; Matsumoto, S. S.; Barrows, L. R.; Ireland, C. M. J. Org. Chem. 1999, 64, 1400.

90. Gunawardana, G. P.; Koehn, F. E.; Lee, A. Y.; Clardy, J.; He, H.; Faulkner, D. J. J. Org. Chem. 1992, 57, 1523.

91. Marshall, K. M.; Holden, Joseph A.; Koller, A.; Kashman, Y.; Copp, B. R. d; Barrows, L. R. Anti-Cancer Drugs. 2004, 15, 907.

92. Copp, B. R.; Jompa, J.; Tahir, A.; Ireland, C. M. J. Org. Chem. 1998, 63, 8024.

93. Rudi, A.; Kashman, Y. J. Org. Chem. 1989, 54, 5331.

94. Blunt, J.W.; Copp, B. R.; Munro, M. H. G.; Northcote, P. T.; Prinsep, M. R. Nat. Prod. Rep. 2003, 20, 1.

95. Molinski T. F.; Ireland, C. M. J. Org. Chem. 1989, 54, 4256.

96. Carroll, A. R.; Cooray, N. M.; Pioner, A.; Scheuer, P. J. J. Org. Chem. 1989, 54, 4231.

97. Kobayashi, J.; Tsuda, M.; Tanabe, A.; Ishibashi, M. J. Nat. Prod. 1991, 54, 1634.

98. Ciufolini, M. A.; Shen, Y. C.; Bishop, M. J. J. Am. Chem. Soc. 1995, 117, 12460.

99. Ciufolini, M.; Shen, Y. Tetrahedron Lett. 1995, 36, 4709.

100. Charylulu, G. A.; McKee, T. C.; Ireland, C. M. Tetrahedron Lett.1989, $30,4201$.

101. Faulkner, D. J. Nat. Prod. Rep. 1990, 7, 269.

102. Rudi, A.; Benayahu, Y.; Goldberg, I.; Kashman, Y. Tetrahedron Lett. 1988, 29, 6655.

103. Ciufolini, M. A.; Byrne, N.E. J. Am. Chem. Soc. 1991, 113, 8016.

104. Echavarren, A. M.; Stille, J. K. J. Am. Chem. Soc. 1988, 110, 4051.

105. Kubo, A.; Nakahara, S. Heterocycles 1988, 27, 2095.

106. Prager, R. H.; Tsopelas, C. Aust J. Chem. 1991, 44, 277. 
107. Prager, R. H.; Tsopelas, C. Heterocycles 1989, 29, 847.

108. Bracher, F. Liebigs Ann. Chem. 1990, 205.

109. Tapia, R. A.; Prieto, Y.; Pautet, F.; Walchshofer, N.; Fillion, H.; Fenet, B.; Sarciron, M. E. Bioorg. Med. Chem. 2003, 11, 3407.

110. Burres, N. S.; Sazesh, S.; Gunawardana, G. P.; Clement, J. J. Cancer Res. 1989, 49, 5267.

111. Lindsay, B. S.; Pearce, A. N.; Copp, B. R. Synth. Commun. 1997, 27, 2587.

112. Alley, M. C.; Pacula-Cox, C. M.; Hursey, M. L.; Rubinstein, L. R.; Boyd, M. R. Cancer Res. 1991, 51, 1247.

113. Plowman, J.; Dykes, D. J.; Hollingshead, M.; Simpson-Herren, L.; Alley, M. C. In: Anticancer Drug Development Guide: Preclinical Screening, Clinical Trials, and Approval, (Ed. B. A. Teicher) Humana Press, Inc., New Jersey, USA, 1997, p. 101.

114. Skipper, H. E.; Schabel Jr., F. M.; Wilcox, W. S.; Laster Jr., W. R.; Trader, M. W.; Thompson, S. A. Cancer Chemother. Rep. 1965, 47, 41.

115. W. R. Waud In: Anticancer Drug Development Guide: Preclinical Screening, Clinical Trials, and Approval (Ed. B. A. Teicher), Humana Press, Inc., New Jersey, USA, 1997, p. 59.

116. Bracher, F. Pharmazie 1997, 52, 57.

117. Boyd, M. R. Principles Practice Oncol. 1989, 3, 1.

118. Longley, R. E.; McConnell, O. J.; Essich, E.; Harmody, D. J. Nat. Prod. 1993, 56, 915.

119. Goulle, Y.; Lehn, J. M.; Sheentjes, B.; Schmitz, F. J. Helv. Chim. Acta 1991, 74, 1471.

120. Lindsay, B. S.; Barrows, L. R.; Copp, B. R. Bioorg. Med. Chem. Lett. 1995, 5, 739.

121. Peterson, J. R.; Zjawiony, J. K.; Liu, S.; Hufford, C. D.; Clark, A. M.; Rogers, R. D. J. Med. Chem. 1992, 35, 4069.

122. Eder, C.; Schupp, P.; Proksch, P.; Wray, V.; Steube, K.; Muller, C. E.; Frobenius, W.; Herderich, M.; van Soest, R. W. M. J. Nat. Prod. 1998, 61, 301.

123. Carter, G.T.; Rinehart, K. L. Jr.; Li, L. H.; Kuentzel, S. L.; Connor, J. L. Tetrahedron Lett. 1978, 4479.

124. Nakagawa, M.; Nagata, T.; Ono, K.; Uchida, H.; Watanabe, T.; Hatakeyama, K.; Akiba, M.; Fuwa, M.; Arisawa, M.; Nishida, A. Adv. Exp. Med. Biol. 2003, 527, 609.

125. Takayama, H.; Ishikawa, H.; Kitajima, M.; Aimi, N.; Aji, B. M. Chem. Pharm. Bull. (Tokyo). 2004, 52, 359.

126. Veluri, R.; Oka, I.; Wagner-Dobler, I.; Laatsch, H. J. Nat. Prod. 2003, 66, 1520.

127. Norton, R. S.; Wells, R. J. J Am. Chem. Soc. 1982, 104, 3628.

128. Pimentel, S. M.; Bojo, Z. P.; Roberto, A. V.; Lazaro, J. E.; Mangalindan, G. C.; Florentino, L. M.; Lim-Navarro, P.; Tasdemir, D.; Ireland, C. M.; Concepcion, G. P. Mar Biotechnol. 2003, 5, 395.

129. Rinehart, K. L. Jr.; Kobayashi, J.; Harboue, G. C.; Gilmore, J.; Mascal, M.; Holt, T. G.; Shield, L. S.; Lafargue, F. J. Am. Chem. Soc. 1987, 109, 3378.

130. Rashid, M. A.; Gustafson, K. R.; Boyd, M. R. J. Nat. Prod. 2001, 64, 1454.

131. van Maarseveen, J. H.; Scheeren, H. W.; De Clercq, E.; Balzarini, J.; Kruse, C. G. Bioorg. Med. Chem. 1997, 5, 955.

132. Van Maarseveen, J. H.; Hermkens, P. H.; De Clercq, E.; Balzarini, J.; Scheeren, H. W.; Kruse, C. G. J. Med. Chem. 1992, 35, 3223.

133. Kobayashi, J.; Taniguchi, M.; Hino, T.; Ohizumi, Y. J. Pharm. Pharmacol. 1988, 40, 62 .

134. Rinehart, K. L., Jr.; Shaw, P. D.; Shield, L. S.; Gloer, J. B.; Harbour, G. C.; Koker, M. E. S.; Samain, D.; Schwartz, R. E.; Tymiak, A. A.; Weller, D. L.; Carter, G. T.; 
Munro, M. H. G.; Hughes, R. G., Jr.; Renis, H. E.; Swynenberg, E. B.; Stringfellow, D. A.; Vavra, J. J.; Coats, J. H.; Zurenko, G. E.; Kuentzel, S. L.; Li, L. H.; Bakus, G. J.; Brusca, R. C.; Craft, L. L.; Young, D. N.; Connor, J. L. Pure Appl. Chem. 1981, 53, 795.

135. Blunt, J. W.; Lake, R. J.; Munro, M. H. G.; Toyokuni, T. Tetrahedron Lett. 1987, $28,1825$.

136. Lake, R. J.; McCombs, J. D.; Blunt, J. W.; Munro, M. H. G.; Robmson, W. T.; Tetrahedron Lett. 1988, 29, 4971.

137. Tsuda, M.; Watanabe, D.; Kobayashi, J. Tetrahedron Lett. 1998, 39, 1207.

138. Kohmoto, S.; Kashman, Y.; McConnel, O.J.; Rinehart, K. L. Jr.; Wright, A.; Koehn, F. J. Org. Chem. 1988, 53, 3116.

139. Morris, S. A.; Anderson, R. J. Tetrahedron 1990, 46, 715. 64.

140. Aubry, C.; Jenkins, P. R.; Mahale, S.; Chaudhuri, B.; Marechal, J. D.; Sutcliffe, M. J. Chem. Commun. (Camb). 2004, 1696.

141. Segraves, N. L.; Robinson, S. J.; Garcia, D.; Said, S. A.; Fu, X.; Schmitz, F. J.; Pietraszkiewicz, H.; Valeriote, F. A.; Crews. P. J. Nat. Prod. 2004, 67, 783.

142. Hormann, A.; Chaudhuri, B.; Fretz, H. Bioorg. Med. Chem. 2001, 9, 917.

143. Soni, R.; Muller, L.; Furet, P.; Schoepfer, J.; Stephan, C.; Zumstein-Mecker, S.; Fretz, H.; Chaudhuri, B. Biochem. Biophys. Res. Commun. 2000, 275, 877.

144. Roll, D. M.; Ireland, C. M.; Lu, H. S. M.; Clardy, J. J. Org. Chem. 1988, 53, 3276.

145. Anthoni, U.; Chevolot, L.; Larsen, C.; Nielsen, P. H.; Christophersen, C. J. Org. Chem. 1987, 52, 4709.

146. Laycock, M. V.; Wright, J. L. C.; Findlay, J. A.; Patil, A. D. Can J. Chem. 1986, 64, 1312.

147. Austin, J. F.; Kim, S. G.; Sinz, C. J.; Xiao, W. J.; MacMillan, D. W. C. Proc. Natl. Acad. Sci. U S A. 2004, 101, 5482.

148. Hino, T. Yakugaku. Zasshi. 1996, 116, 566.

149. Holst, P. B.; Anthoni, U.; Christophersen, C.; Nielsen, P. H. J. Nat. Prod. 1994, 57, 997.

150. Kalinovskaya, N. I.; Ivanova, E. P.; Alexeeva, Y. V.; Gorshkova, N. M.; Kuznetsova, T. A.; Dmitrenok, A. S.; Nicolau, D.V. Curr. Microbiol. 2004, 48, 441.

151. Bailly, C. Curr. Med. Chem. Anti-Cancer Agents 2004, 4, 363.

152. Lovell, F. M. J. Am. Chem. Soc. 1966, 88, 4510.

153. Laatsch, H.; Pudleiner, H. Liebigs Ann. Chem. 1989, 9, 863.

154. Anderson, R. J.; Wolf, M. S.; Faulkner, D. J. J. Mar. Biol. 1974, 24, 281.

155. Tada, H.; Tozyo, T. Chem. Lett. 1988, 803.

156. Bickmeyer, U.; Drechsler, C.; Kock, M.; Assmann, M. Toxicon 2004, 44, 45.

157. Assmann, M.; Zea, S.; Kock, M. J. Nat. Prod. 2001, 64, 1593.

158. Forenza, S.; Minale, L.; Riccio, R.; Fattorusso, E. J. Chem. Soc., Chem. Commun. 1971, 1129.

159. Garcia, E. E.; Benjamin, L. E.; Fryer, R. I. J. Chem. Soc., Chem. Commun. 1973, 78.

160. Olofson, A.; Yakushijin, K.; Horne, D. A. J. Org. Chem. 1998, 63, 5787.

161. Gunasekera, K. L.; Cranik, S.; Longley, R. E. J. Nat. prod. 1989, 52, 757.

162. Kobayashi, J.; Harbour, G. C.; Gilmore, J.; Rinehart, K. L. Jr. J. Am. Chem. Soc. 1984, 106, 1526.

163. Rinehart, K. L. Jr.; Kobayashi, J.; Harbour, G. C.; Hughes, J. R. G.; Mizsak, A.; Scahill, T. A. J. Am. Chem. Soc. 1984, 106, 1524.

164. Kobayashi, J.; Nakamura, H.; Ohizumi, Y.; Hirata, Y. Tetrahedron Lett. 1986, 27, 1191.

165. Kobayashi, J.; Cheng, J. F.; Ohta, T.; Nozoe, S.; Ohizumi, Y.; Sasaki, T. J. Org. Chem. 1990, 55, 3666. 
166. Schupp, P.; Poehner, T.; Edrada, R.; Ebel, R.; Berg, A.; Wray, V.; Proksch, P. J. Nat. Prod. 2003, 66, 272.

167. Mourabit, A. A.; Potier, P. Eur. J. Org. Chem. 2001, 237.

168. Linington, R. G.;Williams, D. E.; Tahir, A.; Van Soest, R.; Anderson, R. J. Org. Lett. 2003, 5, 2735.

169. Forenza, S.; Minale, L.; Riccio, R.; Fattorousso, E. J. Chem. Soc. Chem. Commun. 1971, 18, 1129.

170. Fujita, M.; Nakao, Y.; Matsunaga, S.; Seiki, M.; Itoh, Y.; Yamashita, J.; Van Soest, R. W.; Fusetani, N. J. Am. Chem. Soc. 2003, 125, 15700.

171. Arai, T.; Kubo, A. In: Alkaloids: Chemistry and Pharmacology (edited by A. Brossi) Academic Press, N. Y. 1983, 21, p. 55.

172. Mcintyre, D. E.; Faulkner, D. J.; Van Engen, D.; Clardy, J. Tetrahedron Lett. 1979, 4163.

173. Sandoval, I. T.; Davis, R. A.; Bugni, T. S.; Concepcion, G. P.; Harper, M. K.; Ireland, C. M. Nat. Prod. Res. 2004, 18, 89.

174. Jacobs, R. S.; White, S.; Wilson, L. Feb. Proc. Fed. Am. Soc. Exp. Biol. 1981, 40, 26.

175. Fontana, A.; Caraliere, P.; Wahidullah, S.; Naik, C.G.; Cimino, G. Tetrahedron, 2000, 56, 7305.

176. Pathirana, C.; Anderson, R. J. J. Am. Chem. Soc. 1986, 108, 8288.

177. Kuramoto, M.; Arimoto, H.; Uemura, D. Mar. Drugs 2004, 2, 39.

178. Kuramoto, M.; Chou, T.; Yamada, K.; Chiba, T.; Hayashi, Y.; Uemura, D. Tetrahedron Lett. 1996, 37, 3867.

179. Arimoto, H.; Hayakawa, I.; Kuramoto, M.; Uemura, D. Tetrahedron. Lett. 1998, 39,861 .

180. Trauner, D.; Schwarz, J. B.; Danishefsky, S. J. Angew. Chem. Int. Ed. 1999, 38, 3542 .

181. Trauner, D.; Danishefsky, S. J. Tetrahedron Lett. 1999, 40, 6513.

182. Chou, T.; Haino, T.; Kuramoto, M.; Uemura, D. Tetrahedron Lett. 1996, 37, 3871.

183. Carson, M. W.; Kim, G.; Hentemann, M. F.; Trauner D.; Danishefsky, S. J. Angew. Chem. Int. Ed. 2001, 40, 4450.

184. Carson, M. W.; Kim, G.; Danishefsky, D. J. Angew. Chem, Int. Ed. 2001, 40, 4453.

185. Hayakawa, I.; Arimoto, H.; Uemura, D. Heterocycles 2003, 59, 441.

186. Wu, H.; Nakamaura, H.; Kabayoshi, J.; Ohizumi, Y.; Hirata, Y. Experientia 1986, $42,855$.

187. Oltz, E. M.; Rvuening, R. C.; Smith, M. J.; Kustin, M. J.; Nakanishi, K. J. Am. Chem. Soc. 1988, 110, 6162.

188. DeRosa, S.; De Stefano, S.; Puliti, R.; Matlia, C. A.; Mazzarella, L. J. Nat. Prod. 1987, 50, 876 .

189. Tischler, M.; Ayer, S. W.; Andersen, R. J. Comp. Biochem. Physiol. B. 1986, 84, 43.

190. Fang, Y. I.; Yokota, E.; Mabuchi, I.; Nakamura, H.; Ohizumi, Y. Biochemistry 1997, 36, 15561.

191. Ohizumi, Y. Nippon. Yakurigaku Zasshi. 1992, 100, 259.

192. Takito, J.; Nakamura, H.; Kobayashi, J.; Ohizumi, Y.; Ebisawa, K.; Nonomura, Y. J. Biol. Chem. 1986, 261, 13861.

193. Aiello, A.; Fattorusso, E.; Magno, S.; Misuraca, G.; Novellino, E. Experientia 1987, 43, 950.

194. Kobayashi, J.; Cheng, J. F.; Kikuchi, Y.; Ishibashi, M.; Yamamura, S.; Ohizumi, Y.; Ohta, T.; Nozoe, S. Tetrahedron 1990, 31, 4617.

195. Tsuda, M.; Nozawa, K.; Shimbo, K.; Kobayashi, J. J. Nat. Prod. 2003, 66, 292. 
196. Kobayashi, J.; Cheng, J.-F.; Ohta T.; Nakamura, H.; Nozoe, S.; Hirata, Y.; Ohizumi, Y.; Sasaki, T. J. Org. Chem. 1988, 53, 6147.

197. Kikuchi, Y.; Ishibashi, M.; Sasaki, T.; Kobayashi, J. Tetrahedron Lett. 1991, 32, 797.

198. Shimbo, K.; Tsuda, M.; Fukushi, E.; Kawabata, J.; Kobayashi, J. Tetrahedron 2000, 56, 7923.

199. Tsuda, M.; Nozawa, K.; Shimbo, K.; Kobayashi, J. J. Nat. Prod. 2003, 66, 292.

200. Rao, C. B.; Anjaneyulu, A. S. R.; Sarma, N. S.; Venkateswarlu, Y.; Rosser, R. M.; Faulkner, D. J.; Chem, M. H. M.; Clardy, J. J. Am. Chem. Soc. 1984, 106, 7983.

201. Villar, R. M.; Gil-Longo, J.; Daranas, A. H.; Souto, M. L.; Fernandez, J. J.; Peixinho, S.; Barral, M. A.; Santafe, G.; Rodriguez, J.; Jimenez, C. Bioorg. Med. Chem. 2003, 11, 2301.

202. Nielsen, T. E.; Tanner, D. J. Org. Chem. 2002, 67, 6366.

203. Hikage, N.; Furukawa, H.; Takao, K.; Kobayashi, S. Chem. Pharm. Bull (Tokyo). 2000, 48, 1370.

204. Rao, C. B.; Anjaneyulu, A. S. R.; Sarma, N. S.; Venkatesewarlu, Y.; Rosser, R. M.; Faulkne,r D. J. J. Org. Chem. 1985, 50, 3757.

205. Rao, C. B.; Rao, D. V.; Raju, V. S. N.; Sulivan, B. W.; Faulkner, D. J. Heterocycles 1989, 128, 103.

206. Atta-Ur-Rahman; Alvi, K. A.; Abbas, S. A.; Choudhry, M. I.; Clardy J. Tetrahedron Lett. 1989, 30, 6825.

207. Pettit, G. R.; Inoue, M.; Kamano, Y.; Harard, D. L.; Arm, C.; Dufresne, C.; Christie, N. D.; Schmidt, J. M.; Doubek, D. L.; Krupa, T. S. J. Am. Chem. Soc. 1988, 110, 2006.

208. Flessner, T.; Jautelat, R.; Scholz, U.; Winterfeldt, E. Fortschr. Chem. Org. Naturst. 2004, 87,1 .

209. LaCour, T. G.; Guo, C.; Boyd, M. R.; Fuchs, P. L. Org. Lett. 2000, $2,33$.

210. Pettit, G. R.; Tan, R.; Xu, J.; Ichihara, Y.; Williams, M. D.; Boyd, M. R. J. Nat. Prod. 1998, 61, 955.

211. Pettit, G. R.; Xu, J. P.; Williams, M. D.; Christie, N. D.; Doubek, D. L.; Schmidt, J. M.; Boyd, M. R. J. Nat. Prod. 1994, 57, 52.

212. Pettit, G. R.; Inone, M.; Kamano, V.; Dufresne, C.; Christie, N.; Niven, N. L.; Herald, D. L. J. Chem. Soc. Chem. Commun. 1988, 865.

213. Pettit, G. R.; Kamano, Y.; Dufresne, C.; Inone, M.; Christi, N.; Schmidt, J. M.; Doubek, D.L. Can J. Chem. 1989, 67, 1509.

214. Ishibashi, M.; Ohirzum, Y.; Sasaki, T.; Nakamura, H.; Hirata, Y.; Kobaashi, J. J. Org. Chem. 1987, 52, 450.

215. Quinoa, E.; Crews, P. Tetrahedron Lett. 1987, 28, 2467.

216. Ojika, M.; Yoshida, T.; Yamado, K. Tetrahedron lett. 1993, 34, 5307.

217. Pettit, G. R.; Kantoc, D.; Doubek, D. L.; Tucker, B. E.; Pettit, W. E.; Schrill, R. M. J. Nat. Prod. 1993, 56, 1981.

218. Chan, C. W.; Mong, S.; Heming, M. E.; Freyer, A. J.; Offen, P. H.; BeBrosse, C. W.; Sarau, H. M.; Westley, J. W. J. Nat. Prod. 1993, 56, 116.

219. Gunasekera, S. P.; McCarthy, P. J.; Borges, M. K. J. Nat. Prod. 1994, 57, 1437.

220. Jiang, B.; Yang, C. G.; Wang, J. J. Org. Chem. 2002, 67, 1396.

221. Jiang, B.; Yang, C. G.; Wang, J. J. Org. Chem. 2001, 66, 4865.

222. Casapullo, A.; Bifulco, G.; Bruno, I.; Riccio, R. J. Nat. Prod. 2000, 63, 447.

223. Boyd, K. G.; Harpes, M. K.; Faulkner, D. J. J. Nat. Prod. 1995, 58, 302.

224. Biard, J. F.; Guyot, S.; Roussakis, C.; Verbist, J. F.; Vercauteren, J.; Weber, J. F.; Boukef, K. Tetrahedron Lett. 1994, 35, 2691.

225. Juge, M.; Grimaud, N.; Biard, J. F.; Sauviat, M. P.; Nabil, M.; Verbist, J. F.; Petit, J.-Y. Toxicon 2001, 39, 1231. 
226. Abe, H.; Aoyagi, S.; Kibayashi, C. J. Am. Chem. Soc. 2000, 122, 4583.

227. Abe, H.; Aoyagi, S.; Kibayashi, C. J. Am. Chem. Soc. 2005, 127, 1473.

228. Yosief, T.; Rudi, A.; Kashman, Y. J. Nat. Prod. 2000, 63, 299

229. Yosief, T.; Rudi, A.; Stein, Z.; Goldberg, I.; Gravalos, G. M. D.; Schleyer, M.; Kashman, Y. Tetrahedron Lett. 1998, 39, 1445.

230. Pappo, D.; Shimony, S.; Kashman, Y. J. Org. Chem. 2005, 70, 199.

231. de Oliveira, J. H. H. L.; Grube, A.; Kock, M.; Berlinck, R, G. S. Macedo, M. L.; Ferreira, A. G.; Hajdu, E. J. Nat. Prod. 2004, 67, 1685. 